\title{
Eustatic versus tectonic control in an intraplate rift basin (Leza Fm, Cameros Basin). Chronostratigraphic and paleogeographic implications for the Aptian of Iberia
}

\author{
Control eustático versus control tectónico en una cuenca de rift intraplaca \\ (Fm Leza, Cuenca de Cameros). Implicaciones cronoestratigráficas y \\ paleogeográficas para el Aptiense de Iberia
}

\author{
P. Suarez-Gonzalez ${ }^{1,2, *}$, I. E. Quijada ${ }^{1,2,}$, M. I. Benito ${ }^{1,2}$, R. Mas ${ }^{1,2}$ \\ ${ }^{1}$ Departamento de Estratigrafía, Fac. Ciencias Geológicas, Universidad Complutense de Madrid, 28040 Madrid, Spain \\ 2.Instituto de Geociencias IGEO (CSIC, UCM), C/ José Antonio Novais 12, 28040 Madrid, Spain \\ pablosuarez@geo.ucm.es; equijada@geo.ucm.es; maribel@geo.ucm.es; ramonmas@geo.ucm.es \\ *corresponding author
}

Received: 20/04/2013 / Accepted: 10/07/2013

\begin{abstract}
The Leza Formation is a carbonate unit of the northern Cameros Basin (N Spain) with controversial age, stratigraphic position, and sedimentological interpretation. It was deposited in a series of fault-bounded tectonic depressions along the northern margin of the basin. The Leza Fm overlies and changes laterally to the siliciclastic Jubera Fm, and the thickness of both units is also controlled by faults. Although the Leza Fm has been traditionally interpreted as lacustrine with sporadic marine incursions, detailed sedimentological analysis reveals new and very abundant evidences of marine influence: sedimentary structures of tidal origin, common marine fossils (dasycladales and foraminifers), and homogeneous populations of porocharacean charophytes, indicative of brackish conditions. Thus, this unit is interpreted as deposited in a system of coastal-wetlands with both fresh-water and sea-water influence, laterally related with the alluvial deposits of the Jubera Fm and the fluvio-lacustrine deposits of the Enciso Gr towards the centre of the basin. Using the chronostratigraphic ranges of the marine fossils and the lateral relationship with adjacent units, the Leza Fm is confirmed as part of a depositional sequence late Barremian - early Aptian in age. Furthermore, a transgressive trend is defined in the Leza Fm, which is compared with the eustatic evolution of the neighbouring Basque-Cantabrian, Iberian and Pyrenean marine basins, allowing correlation of the upper part of this unit with the widespread eustatic maximum of the middle-upper part of the early Aptian. This eustatic influence provided additional accommodation space to that created by tectonics.

These data from the Cameros Basin are contrasted with a thorough compilation of paleogeographic data, showing that, during the early Aptian transgression, marine influence was likely to reach the northern Cameros Basin, not only coming from the SE Iberian Basin, as previously interpreted, but also from the NW Basque-Cantabrian Basin. This resulted in a probable link between Boreal and Tethyan marine realms
\end{abstract}

Keywords: Lower Cretaceous, paleogeography, Iberian plate, tectonics vs. eustasy, coastal lakes, Spain 


\section{Resumen}

La Formación Leza es una unidad carbonática del norte de la Cuenca de Cameros (N España), cuya edad, posición estratigráfica e interpretación sedimentológica son controvertidas. Se depositó en una serie de cubetas tectónicas limitadas por fallas a lo largo del borde norte de la cuenca. La Fm Leza yace sobre y pasa lateralmente a los depósitos siliciclásticos de la Fm Jubera, estando el espesor de ambas unidades también controlado por fallas. Pese a que la Fm Leza ha sido tradicionalmente interpretada como lacustre con incursiones marinas esporádicas, el análisis sedimentológico detallado revela nuevas evidencias muy abundantes de influencia marina: estructuras sedimentarias de origen mareal, y habituales fósiles marinos (dasycladales y foraminíferos), así como poblaciones homogéneas de carofitas porocaráceas, que indican medios salobres. Esta unidad se interpreta como formada en un sistema de humedales costeros con influencia tanto de agua dulce como de agua marina, relacionado lateralmente con los depósitos aluviales de la Fm Jubera y con los depósitos fluvio-lacustres del Gr Enciso hacia el centro de la cuenca. Usando los rangos cronoestratigráficos de los fósiles marinos y las relaciones laterales con unidades adyacentes, se confirma la pertenencia de la Fm Leza a la secuencia deposicional de edad Barremiense superior - Aptiense inferior. Además, se define una tendencia transgresiva en la Fm Leza, que al ser comparada con la evolución eustática de las cuencas marinas coetáneas, Vasco-Cantábrica, Ibérica y Pirenaica, permite la correlación de la parte superior de esta unidad con el máximo eustático generalizado de la parte media-superior del Aptiense inferior. Esta influencia eustática produjo un espacio de acomodación adicional al producido por la tectónica.

Estos datos de la Cuenca de Cameros son contrastados con una recopilación exhaustiva de datos paleogeográficos, mostrando que durante la transgresión del Aptiense inferior, la influencia marina probablemente alcanzó el norte de la Cuenca de Cameros no sólo desde la Cuenca Ibérica al SE, como ha sido interpretado previamente, sino también desde la Cuenca Vasco-Cantábrica al NO. Esto produciría la probable unión entre los ámbitos del Océano Boreal y del Tetis.

Palabras clave: Cretácico Inferior, paleogeografía, Placa Ibérica, tectónica vs. eustatismo, lagos costeros, España

\section{Introduction}

Tectonics and eustasy are the main allocyclic factors controlling the creation of accommodation space in sedimentary basins (e.g. Ingersoll and Busby, 1995; Bosence, 1998; Miall and Miall, 2001; Leeder, 2011). In general, tectonics can be regarded as the most important factor, especially in rift basins, because in them, crustal extension is typically expressed in surface as faults on the basin substrate, which generate accommodation space that will be filled by sediments (Leeder and Gawthorpe, 1987; Leeder, 1995; Gawthorpe and Leeder, 2000). But if a rift basin is close to the marine realm, rising and falling of sea-level will be an additional factor controlling accommodation space (Pietman, 1978; Lambeck et al., 1987; Leeder and Gawthorpe, 1987; Ravnas and Steel, 1998). When both factors are actively found together, as in coastal/marine rifts and proto-oceanic rift troughs (Leeder, 1995; Ravnas and Steel, 1998; Gawthorpe and Leeder, 2000), they create a complex combination which has proved to be difficult to untangle (Lambeck et al., 1987; Miall and Miall, 2001; De Benedictis et al., 2007). In these cases, detailed tectonic and sedimentological studies are necessary to discriminate their relative roles on the generation of accommodation space (Pietman, 1978; Lambeck et al., 1987; Collier, 1990; Gawthorpe et al., 1997; Cross et al., 1998; Perrin et al., 1998; Plaziat et al., 1998; Ravnas and Steel, 1998; Miall and Miall, 2001). Here we present the case study of a coastal carbonate unit (Leza Formation) deposited on the active margin of an intraplate rift basin (Cameros Basin), during a period of significant eustatic rise.
In this work, detailed geological mapping and outcrop analysis are used to interpret the tectonic control of the Leza Fm, which was deposited in a series of small faultbounded depressions along the northern margin of the Cameros rift basin. In addition, sedimentological analysis is carried out in order to accurately describe the marine influence in the Leza Fm deposits. The aim of this study is to compare this marine influence with the tectonic setting of the Leza Fm, which would allow differentiation between the relative roles of eustasy and tectonics as factors controlling the generation of accommodation space and the sedimentation of the unit.

Furthermore, this study provides new data on the controversial age of the Leza Fm. These data, together with the new evidences of marine influence, are an interesting source of paleogeographic information, and they lead to a reinterpretation of the sources of marine influence on the Leza Fm, as well as a revision of the early Aptian paleogeography of NE Iberia.

\section{Geological setting}

The Cameros Basin is the northwesternmost basin of the Mesozoic Iberian Rift System (Fig. 1). It was formed during Late Jurassic to Early Cretaceous times, and it was inverted during the Cenozoic Alpine Orogeny (Casas-Sainz and Simón-Gómez, 1992; Mas et al., 1993; Guimerà et al., 1995). The sedimentary infill of the basin was deposited on top of a Triassic-Jurassic substrate during Tithonian to early Albian times, and it is composed of sedimentary rocks deposited in continental and transitional 


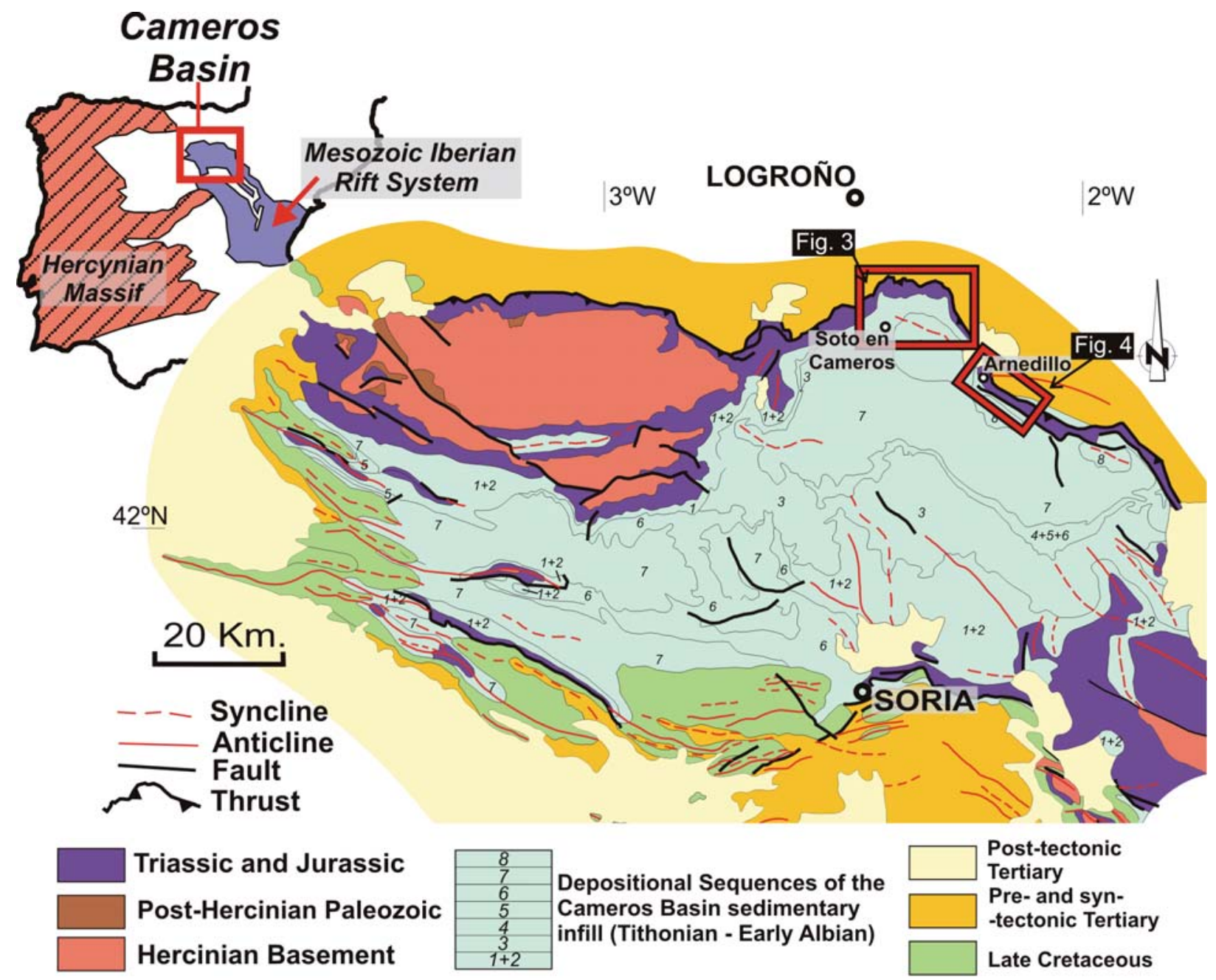

Fig. 1.- Geological map of the Cameros Basin, showing its location on the Iberian Peninsula and in the Mesozoic Iberian Rift System (upper left). Red squares show approximate situation of the geologic maps of Figures 3 and 4. Modified after Mas et al., 2002a.

Fig. 1.- Mapa geológico de la Cuenca de Cameros. Arriba a la izquierda se muestra su situación en la Península Ibérica y en el Sistema Mesozoico de Rift Ibérico. Los recuadros rojos muestra la localización aproximada de los mapas geológicos de las Figuras 3 y 4. Modificado de Mas et al., 2002a.

environments (Tischer, 1966; Salomon, 1982; Guiraud \& Seguret, 1985; Alonso and Mas, 1993; Mas et al., 1993; 2011; Quijada et al., 2010; 2013; 2014; Suarez-Gonzalez et al., 2010; 2012). This sedimentary infill has a vertical thickness of up to $6000 \mathrm{~m}$ and it was originally divided by Tischer (1966) in five lithostratigraphic groups (Tera Gr, Oncala Gr, Urbión Gr, Enciso Gr, and Oliván Gr). These denominations are still in use, but were adapted to sequence stratigraphy (Mas et al., 1993) and are currently divided in eight depositional sequences (Mas et al., 2002a; 2004; 2011; Fig. 2).

The Leza Fm is a carbonate unit with strongly variable thickness (from less than $20 \mathrm{~m}$ to almost $280 \mathrm{~m}$ ), because it crops out in a discontinuous series of small lithosomes along the northern margin of the basin (Díaz Martínez, 1988; Alonso and Mas, 1993; Suarez-Gonzalez et al., 2010; 2011) (Figs. 1, 3, 4). These lithosomes include the Leza Fm and the underlying Jubera Fm, and they are limited by faults that fracture the Mesozoic substrate of the Cameros Basin. The Jubera Fm, which also shows a strongly variable thickness (Fig. 3, 4), consists of conglomerates, sandstones and shales. Deposits of the Jubera Fm are interpreted as formed in alluvial fans related to the erosion of the faulted substrate (Alonso and Mas, 1993). The Leza Fm is mainly composed of limestones, dolomites and marls but it also contains variable siliciclastic influence (conglomerates and sandstones). It was attributed to lacustrine and palustrine environments with levels of marine influence (Guiraud, 1983; Alonso and Mas, 1993). The lithosomes of the Jubera and Leza units are overlaid by mixed siliciclastic-carbonate facies of the Enciso Group (Figs. 2, 3, 4).

Outcrops of the Leza Fm can be divided in two main sectors, which are separated by an extensive outcrop of Tertiary rocks (Figs. 1, 3, 4). The Western sector is located between the valleys of the Leza River and the Jubera 


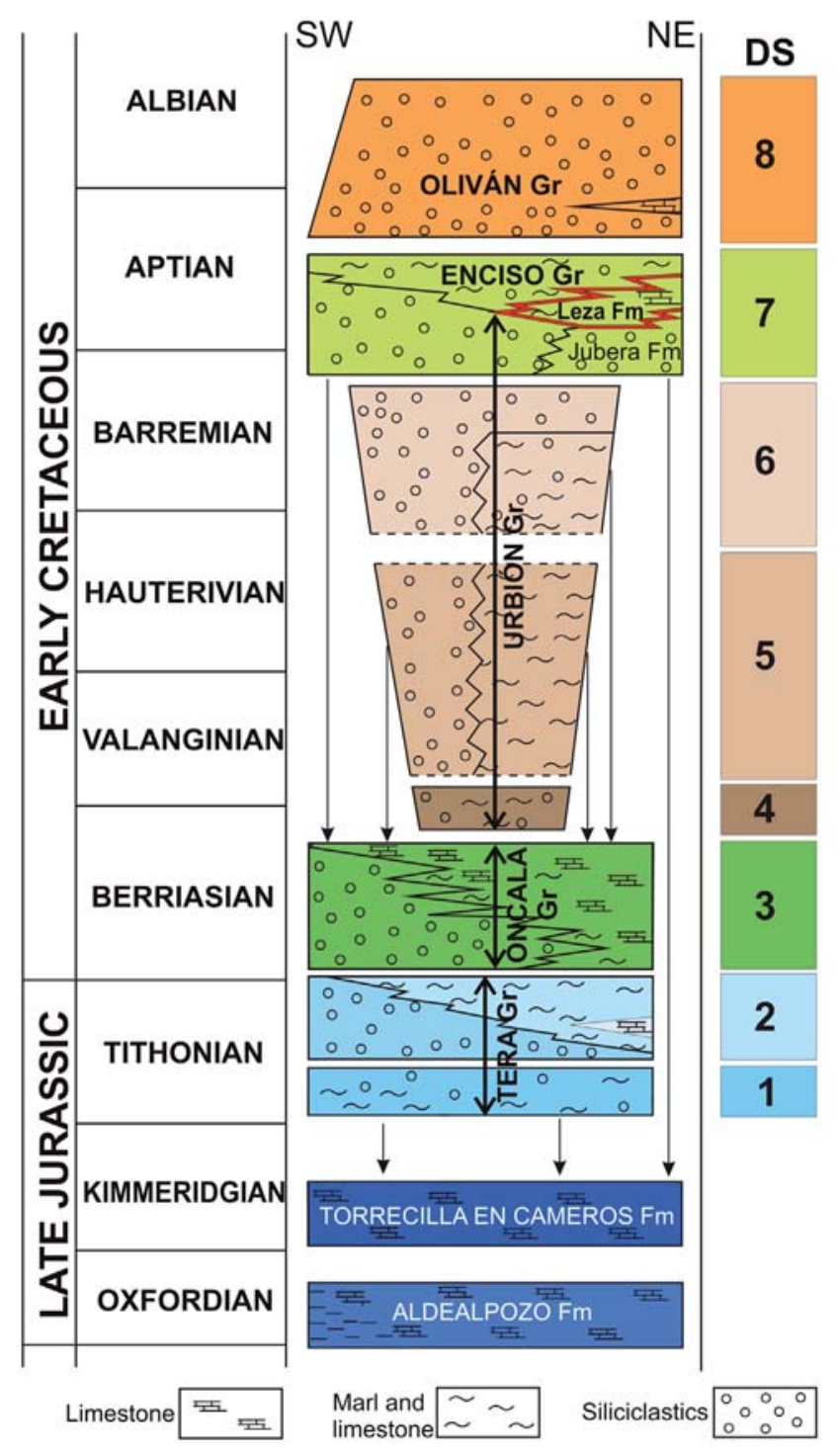

Fig. 2.- Chronostratigraphic chart of the Cameros Basin, showing part of the Upper Jurassic substrate of the basin and the Tithonian-Albian sedimentary record, divided in 8 depositional sequences (DS). The Leza Fm is outlined in red. Modified after Mas et al., 2011.

Fig. 2.- Cuadro cronoestratigráfico de la Cuenca de Cameros, que muestra parte del sustrato Jurásico Superior de la cuenca y su relleno sedimentario, Tithoniense-Albiense, dividido en 8 secuencias deposicionales (DS). La Fm Leza está resaltada en rojo. Modificado de Mas et al., 2011.

River (La Rioja, Spain) and contains three lithosomes: San Vicente, San Martín and Leza lithosomes (Figs. 1, 3). The Eastern sector is located around the Cidacos River valley between the towns of Arnedillo and Préjano (La Rioja, Spain) and contains five lithosomes of the Jubera and Leza Fms: Préjano, Peñalmonte, Arnedillo, Canteras and Castellar lithosomes (Figs. 1, 4).

\subsection{Ages previously attributed to the Leza Fm}

Due to the scarcity of high resolution biostratigraphic data, the sedimentary record of the Cameros Basin is diffi- cult to date accurately (Martín-Closas and Alonso, 1998) and, in particular, the Leza Fm has been given many different ages, ranging from Berriasian to Aptian (Fig. 5). The Leza Fm was defined as a formal lithostratigraphic unit by Mas et al. (1990), but its deposits were mentioned in previous studies. Tischer (1966) briefly described the carbonates of the Leza Fm throughout the northern margin of the basin, and he stated that they change laterally to the Enciso Gr. Based on ostracod biostratigraphy, Kneuper-Haack (1966) assigned a Berriasian age to the Enciso Gr, and Brenner \& Wiedmann (1975) dated the Enciso Gr as Hauterivian-Barremian. Salomon (1982) redefined the age of the Enciso Gr as early Valanginian, based on mapping and stratigraphic relationships. However, Salomon (1982) did not consider the deposits of the Leza Fm as a uniform unit: in the Leza River area (Fig. 3) they are mapped as equivalent to the Enciso Gr of Tischer (1966), but in the Jubera River (Fig. 3) and Arnedillo (Fig. 4) areas they are considered as equivalent to the Tera Gr of Tischer (1966). Guiraud (1983) was the first to recognize the Leza Fm deposits as a lithostratigraphic unit, which he informally named série Soto. He also named the Jubera Fm as série Leza. He considered the Jubera Fm as part of the Urbión Gr and the Leza Fm as part of the Enciso Gr, both early Valanginian in age, following the chronostratigraphy of Salomon (1982). Guiraud (1983) found dasycladales in the Arnedillo section, interpreting for the first time marine influence in the deposits of the Leza Fm. Schudack (1987) further refined the age of the Enciso Gr, using ostracods and charophytes, as Barremian. Díaz Martínez (1988) recognized that the Jubera and the Leza Fms are tectonically controlled, also describing a lateral relationship between both units. Hernández Samaniego et al. (1990) used regional lithologic correlations and scarce charophyte data to assign the deposits of the Jubera Fm and Leza Fm as Kimmeridgian-Berriasian (Tera Gr of Tischer, 1966) and Berriasian (Oncala Gr), respectively. In contrast, Mas et al. (1990) used previous data to assign a Valanginian-Barremian age to both units. Alonso and Mas (1993) described lateral relationship between the Leza Fm and the Enciso Gr. They mentioned sporadic occurrence of dasycladales and foraminifers in the Leza Fm and, given the age of the overlying units and the chronostratigraphic range of the dasycladales, they considered the Enciso Gr as Barremian-Aptian in age. Mas et al. (1993) refined this age as upper Barremian-lower Aptian. Casas-Sainz and Gil-Imaz (1994) did not discuss chronostratigraphy of the Cameros Basin, and they did not mention the Leza Fm as a unit, but in their Figura 3 presented an outcrop sketch of the Préjano area (Fig. 4) where the Leza Fm deposits are classified as part of the Enciso Gr. In addition, their Figura 8 showed a geological 


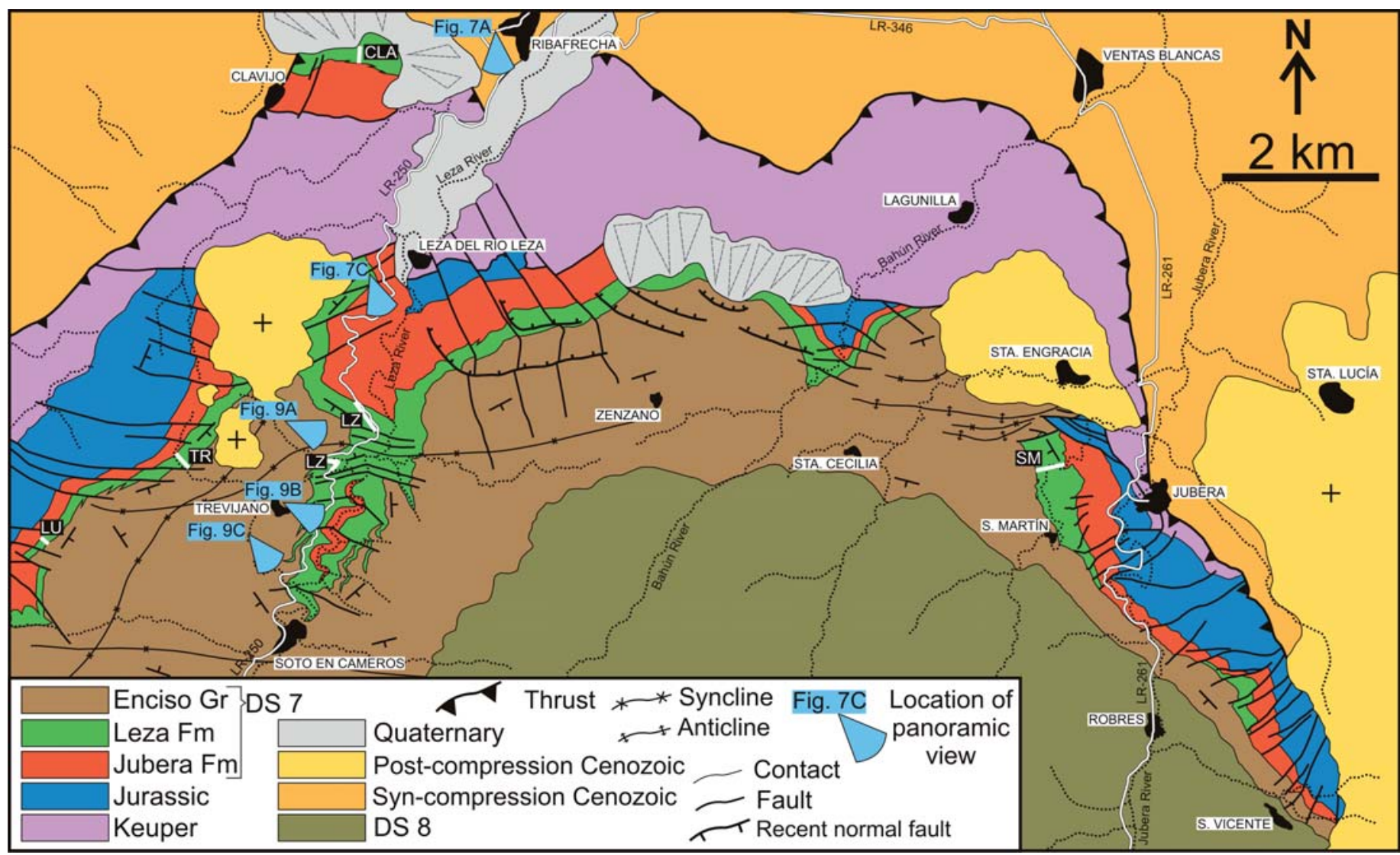

Fig. 3.- Geological map of the western outcrops of the Leza Fm and their surrounding areas. White lines marked in the Leza Fm outcrops represent measured stratigraphic sections. DS: Depositional sequence (see Fig. 2). LU: Luezas section; TR: Trevijano section; LZ: Leza River section; CLA: Clavijo Section; SM: San Martín Section.

Fig. 3.- Mapa geológico de los afloramientos occidentales de la Fm Leza y de las áreas que los rodean. Las líneas blancas representan las secciones estratigráficas medidas en la Fm Leza para este trabajo. DS: Secuencia desposicional (ver Fig. 2). LU: columna de Luezas; TR: columna de Trevijano; LZ: columna del Río Leza; CLA: columna de Clavijo; SM: columna de San Martín.

map of the Arnedillo area (Fig. 4) where outcrops of the Leza Fm are attributed to the Oncala Gr. Martín-Closas and Alonso (1998) conducted a thorough chronostratigraphic study of the Cameros Basin, including data from ostracods, charophytes, palynomorphs and dasycladales, as well as data from geological mapping and regional stratigraphic correlations. For them, the Leza Fm is part of the Enciso Gr, which is upper Barremian-lower Aptian in age. Mas et al. (2002a; 2004) updated the sequence stratigraphic framework of the basin, including the Jubera and Leza Fms in the seventh depositional sequence (DS7, Fig. 2), upper Barremian-lower Aptian in age. Doublet (2004) studied the Enciso Gr and considered that the Leza Fm belongs to the Oncala Gr. Schudack and Schudack (2009) changed the previous ostracod biostratigraphy of the Cameros Basin, considering the Enciso Gr as upper Valanginian-Barremian in age. Casas et al. (2009) did not discuss chronostratigraphy of the Cameros Basin, but in their Figure 8 they showed outcrop photographs of the Jubera Fm and the Leza Fm deposits in the Leza River area (Fig. 3), in which they are considered as part of the Oncala Gr and Enciso Gr, respectively. Suarez-Gonzalez et al. (2010) presented new occurrences of dasycladales (Salpingoporella urladanasi) and foraminifers in the Leza Fm, suggesting that marine influence was more important than previously thought and confirming this unit as part of the Enciso Gr, Barremian-Aptian in age, based on the stratigraphic range of that species (Carras et al., 2006). Clemente (2010) considered the Leza Fm as part of the Oncala Gr, lower-middle Berriasian in age, using the criteria of Hernández Samaniego et al. (1990).

In this study we present new stratigraphic, sedimentological and paleontological data, as well as a new detailed geological mapping that will shed some light on the controversial chronostratigraphy of the Leza Fm and the Cameros Basin.

\section{Methods}

This work is based on detailed geological mapping and sedimentological and paleontological analysis of the Leza Fm, as well as on a thorough revision of the literature concerning the chronostratigraphic and paleogeographic context of the Leza Fm. 


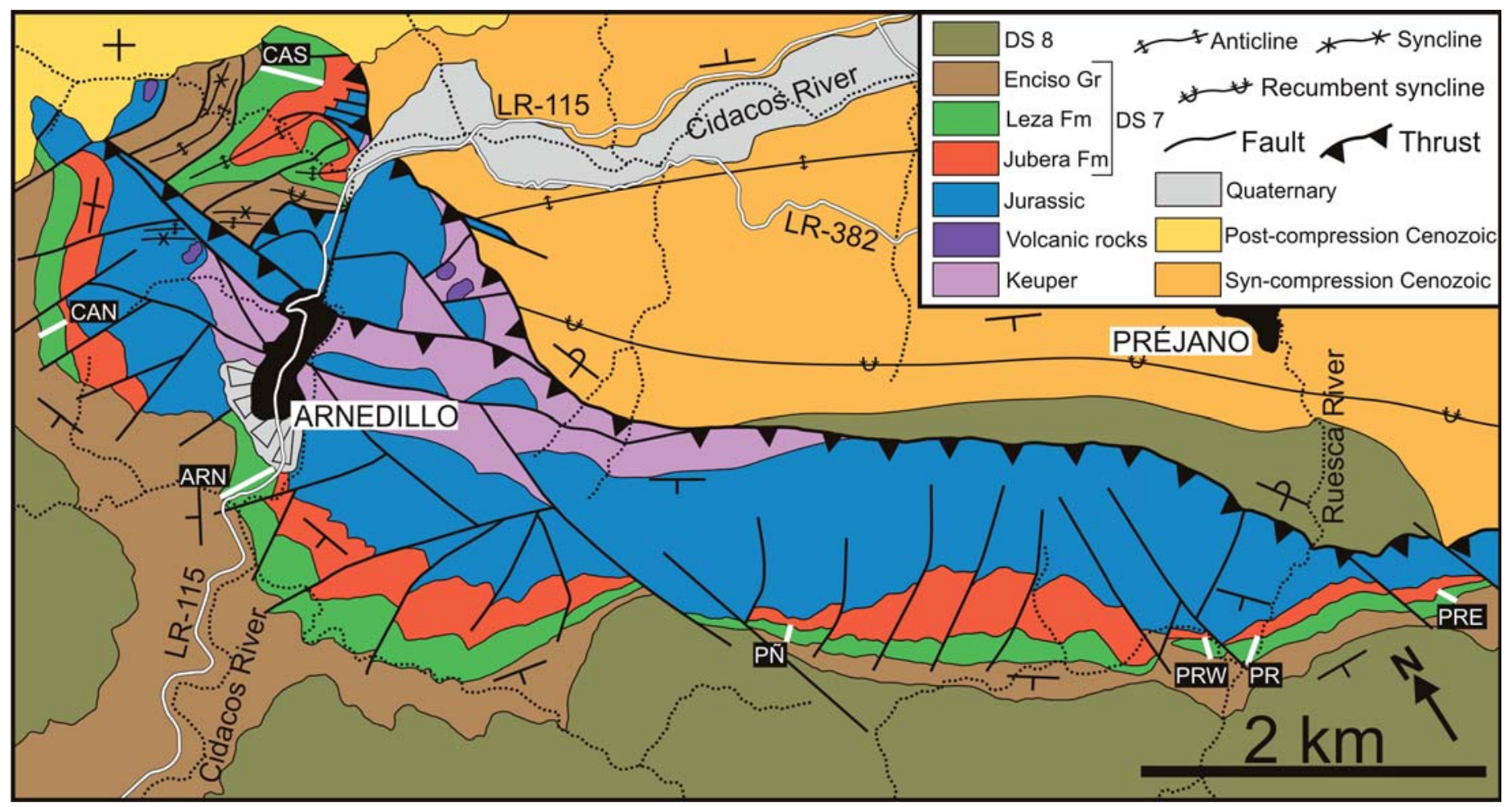

Fig. 4.- Geological map of the eastern outcrops of the Leza Fm, and their surrounding areas. White lines marked in the Leza Fm outcrops represent measured stratigraphic sections. DS: Depositional sequence (see Fig. 2). CAS: Castellar section; CAN: Canteras section; ARN: Arnedillo section; PÑ: Peñalmonte section; PRW: Préjano West section; PR: Préjano section; PRE: Préjano East section.

Fig. 4.- Mapa geológico de los afloramientos orientales de la Fm Leza y de las áreas que los rodean. Las líneas blancas representan las secciones estratigráficas medidas en la Fm Leza para este trabajo. DS: Secuencia desposicional (ver Fig. 2). CAS: columna de Castellar; CAN: columna de Canteras; ARN: columna de Arnedillo; PÑ: columna de Peñalmonte; PRW: columna de Préjano Oeste; PR: columna de Préjano; PRE: columna de Préjano Este.

For the work on the Leza Fm, an approximate area of $240 \mathrm{~km}^{2}$ was mapped at 1:5000 scale using field observations, aerial photographs and satellite images. ArcGIS software was used to integrate all the cartographic data and to elaborate the final simplified synthetic maps (Fig. $3,4)$. Twelve complete stratigraphic sections of the Leza Fm have been measured (Fig. 6) with a decimetre resolution and logged at 1:100 scale. The base of the sections corresponds to the contact between Jubera Fm and Leza Fm, which is gradational and, in this work, it is located at the first meter-scale carbonate bed found in the upper part of the Jubera Fm. The contact between the Leza Fm and the overlying Enciso Gr is also gradational and, in this work, the base of the Enciso Gr is considered to be marked by the first occurrence of decimetre-scale alternation of marls, sandstones and sandy ostracod-rich limestones, which are characteristic facies of the Enciso $\mathrm{Gr}$ (Mas et al., 1993; Alonso-Azcárate, 1997; Doublet et al., 2003). 750 rock samples were collected from the stratigraphic sections, as well as from other outcrops. A polished and uncovered thin section $(30 \mu \mathrm{m}$ thick) was prepared for each sample, in order to conduct petrographic analysis. Thin sections were partially stained with Alizarin Red S and potassium ferricyanide (Dickson, 1966), for accurate distinction between calcite and dolomite. The petrographic and sedimentological description of this work will follow the classification of carbonate rocks of Dunham (1962).

For the interpretation of the paleogeographic context of the Leza Fm, we have elaborated a comprehensive compilation of information regarding the early Aptian in Northern and Eastern Spain. The main source of data for this compilation was the 1:50000 geological map of Spain (MAGNA series, available from the Geological Survey of Spain, IGME, and the Geological Survey of Catalunya, IGC). 212 maps of this series (see Appendix) have been carefully examined looking for lower Aptian outcrops. Additional information has been obtained from works of regional geology (Peybernès, 1976; Mas, 1982; Meléndez, 1983; Salas, 1987; Alonso and Mas, 1988; García-Mondéjar, 1990; Berástegui et al., 2002; GarcíaSenz 2002; Rosales et al., 2002; Mas et al., 2002b; 2004; García-Mondéjar et al., 2004; Robador and García-Senz, 2004; González Fernádez et al., 2004). Borehole data have also been used for the paleogeographic reconstruction. A compilation of data from exploration wells edited by IGME (1987) has been used. Several previous paleogeographic reconstructions have been also used in order 
to complete our reconstruction of areas where data were not available (Ziegler, 1988; Hay et al., 1999, Masse et al., 2000; Berástegui et al., 2002; Rosales et al., 2002; Mas et al., 2002b; 2004; García-Mondéjar et al., 2004; Robador and García-Senz, 2004; as well as the paleogeographic maps of Ronald Blakey, available at http:// www2.nau.edu/rcb7).

\section{Results}

\subsection{Geological mapping, tectonic framework and relationships with adjacent units}

Geological maps of the northern margin of the Cameros Basin (Figs. 3, 4) show that the Leza Fm and the underlying Jubera Fm crop out discontinuously, on a series of lithosomes limited by faults that fracture the Mesozoic (Jurassic and Triassic) substrate of the basin. These lithosomes are arranged in a NW-SE direction, parallel to the northern thrust of the Cameros Basin, and they are overlain by the Enciso Gr. Furthermore, smaller-scale faults are observed inside the lithosomes, which control the thickness of the Jubera Fm and the Leza Fm (Figs. 3, 4). Both units are typically thicker in the middle part of the lithosomes and they thin towards the limits, disappearing laterally in many cases, which locally allows the Enciso Gr to be directly on top of the Jurassic substrate (Fig. 4). The faults that limit the lithosomes and those which control the thickness of the Jubera and Leza Fms do not seem to significantly affect the overlying Enciso Gr.

This general tectonic framework of the northern margin of the Cameros Basin shows that the siliciclastic Jubera Fm and the carbonate Leza Fm are tectonically related. Furthermore, transition between both units is gradational: the top of the Jubera Fm contains progressively more abundant calcareous sandstones and thin limestone levels (Ochoa, 2006); the base of the Leza Fm is rich in clastic facies (mainly conglomerates and sandstones with fragments of Jurassic limestone, similar to those of the Jubera Fm), which gradually disappear towards the top of the unit (Fig.6). This gradual transition between both units suggests a lateral relationship of facies. Figure 7A shows

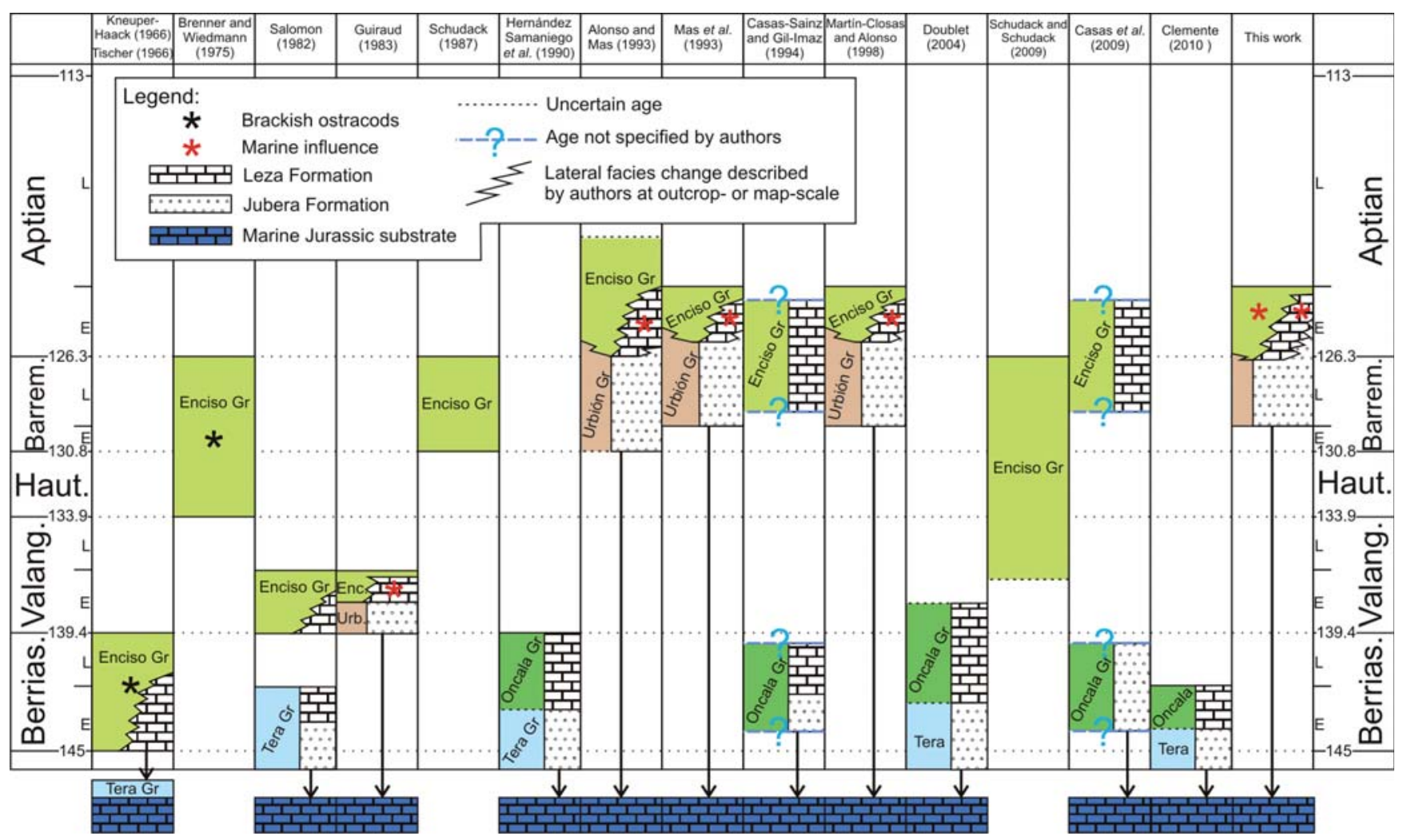

Fig. 5.- Comparative chronostratigraphic chart summarising the different ages and lithostratigraphic frameworks that have been proposed for the units of the northernmost area of the Cameros Basin. When authors assigned the Jubera and Leza Fms to a particular lithostratigraphic group but did not specified its age, we assumed the ages used in this work for the lithostratigraphic groups (Fig. 2). Lateral facies change was depicted only when authors clearly describe it either in text, maps or figures. Early Cretaceous geochronology from Ogg and Hinnov (2012).

Fig. 5.- Cuadro cronoestratigráfico comparativo que resume las diferentes edades y marcos litoestratigráficos propuestos para las unidades del borde norte de la Cuenca de Cameros. Cuando los autores asignan las Fms Jubera y Leza a un determinado grupo litoestratigráfico sin especificar la edad, hemos asumido las edades de los grupos litoestratigráficos usadas en este trabajo (Fig. 2). Se ha dibujado un cambio lateral de facies únicamente cuando los autores lo describían inequívocamente ya fuera en el texto, en un mapa o en una figura. La geocronología del Cretácico Inferior es de Ogg and Hinnov (2012). 
a panoramic view of "Peñas de Leza" seen from the town of Ribafrecha to the North (see exact location in Fig. 3). In this view it can be observed that the upper strata of the Jubera Fm are westward changing to the lower strata of the Leza Fm, producing a progressive eastward thinning of the Leza Fm (Fig. 7B). This lateral relationship can also be observed at a smaller scale (Fig. 7C).

Geological maps (Figs. 3, 4) show that the Leza Fm is always overlain by part of the Enciso Gr, which is a thick unit (up to $1100 \mathrm{~m}$ in its depocentre) formed by a wellbedded alternation of sandstones, siliciclastic mudstones, marls, limestones and dolomites (Mas et al., 1993; Alonso-Azcárate, 1997; Alonso-Azcárate et al., 1999; Doublet et al., 2003), worldwide-known for the abundance of dinosaur footprints (Moratalla and Sanz, 1997; PérezLorente, 2002; Moratalla and Hernán, 2010). Transition from the Leza to the Enciso deposits is also typically gradual, which causes interbedding of thin-bedded marls and sandy limestones of the Enciso Gr with thicker-bedded carbonates of the Leza Fm at the contact of both units (Fig. 8). The relationship between the Leza Fm and the Enciso Gr is clearly seen in the Leza River valley. Figure 9 shows N-S panoramic photographs of the eastern side of the valley, taken from the West (see Fig. 3 for exact location). These panoramic views show that levels of the Leza Fm (seen in the field as hard carbonate packages producing marked topographic relief) gradually pass to the south to Enciso Gr levels (seen in the field as more erodible and vegetated alternations of marls, carbonates and sandstones). This transition creates a southwards facies change from the Leza Fm to the Enciso Gr (Fig. 3). The southern limit of this lateral facies change is located around the village of Soto en Cameros (Fig. 9C), where the Enciso Gr deposits predominate, displaying its characteristic lithologies and facies (Tischer, 1966, Salomon, 1982; Guiraud, 1983; Mas et al., 1993; 2011), as well as its characteristic paleoichnological content (Casanovas et al., 1990; 1992; Moratalla and Hernán, 2010).

\subsection{Sedimentology of the Leza Fm}

The detailed sedimentological analysis of all the measured sections of the Leza Fm (Fig. 6) has led to the recognition of many different facies that can be grouped and summarized in five facies associations

a) The clastic facies association is very abundant in the lower part of most of the studied sections of the Leza Fm and its abundance decreases upwards (Fig. 6). It includes conglomerates, cross-bedded sandstones, and less common marls. Conglomerates are poorly sorted and generally matrix-supported. They are composed of lithoclasts of Jurassic limestones, quartz and quartzite pebbles, and carbonate intraclasts, within a sandy matrix (Fig. 10A). Sandstones are coarse- to fine-grained and commonly contain fragments of Jurassic limestone. The sandstone bodies typically show irregular bases, fining-upward trends, and trough cross-bedding. This facies association is interpreted as formed in an alluvial system whose main source area was the marine Jurassic limestones from the substrate of the Cameros Basin, which was faulted (Fig. 3, 4) and, therefore, exposed and being actively eroded during the sedimentation of the Leza Fm (Suarez-Gonzalez et al., 2010; 2014).

b) The black limestones facies association comprises the most characteristic facies of the Leza Fm. It occurs both in the lower and upper part of all the studied sections (Fig. 6). This facies association is typically arranged in thickening-upwards sequences, 1-4 $\mathrm{m}$ thick (Fig. 10B), formed by black bioclastic limestones and less abundant marls. Limestones generally have mudstonewackestone textures in the lower part of the sequences and wackestone-packstone textures in the upper part of the sequences. The top of these sequences is marked by features such as mud cracks, abundant bioturbation, root traces, brecciated horizons, nodular and mottled horizons, vertebrate footprints, and ferruginous surfaces (Fig. 10C). Black limestones of the lower part of the Leza Fm are generally sandy, whereas quartz grains are rarer in limestones of the upper part. They contain bioclasts, intraclasts and very abundant oncoids. The bioclasts are ostracods, charophytes, gastropods, dasycladales, filamentous microbial colonies, and fragments of vertebrate bones and egg-shells (Fig. 10D). These bioclasts lack any signs of reworking (Fig. 10D) and, therefore, they are considered as in situ remains valid for paleoenvironmental interpretations. Some sequences of the western outcrops of the Leza Fm (Trevijano and Leza sections, Fig. 6) contain skeletal stromatolites (Suarez-Gonzalez et al., 2014). The sequences of this facies association are interpreted as shallowing-upward sequences of shallow bodies of water (Suarez-Gonzalez et al., 2010; 2014). The common presence of in situ microfossils of both continental and marine affinities (charophytes and dasycladales, respectively) suggests that these bodies of water were coastal-lakes with influence of both fresh-water and marine water (Suarez-Gonzalez et al, 2010; in press). Areas between coastal-lakes were probably covered by vegetation, since the top of the shallowing-upward sequences contain characteristic features of edaphic alteration and development of paleosoils in carbonates (e.g. Platt and Wright, 1992; Freytet and Verrechia, 2002; Alonso-Zarza and Wright, 2010, and references therein).

c) The oolite-stromatolite facies association has only been observed in the eastern outcrops of the Leza Fm 

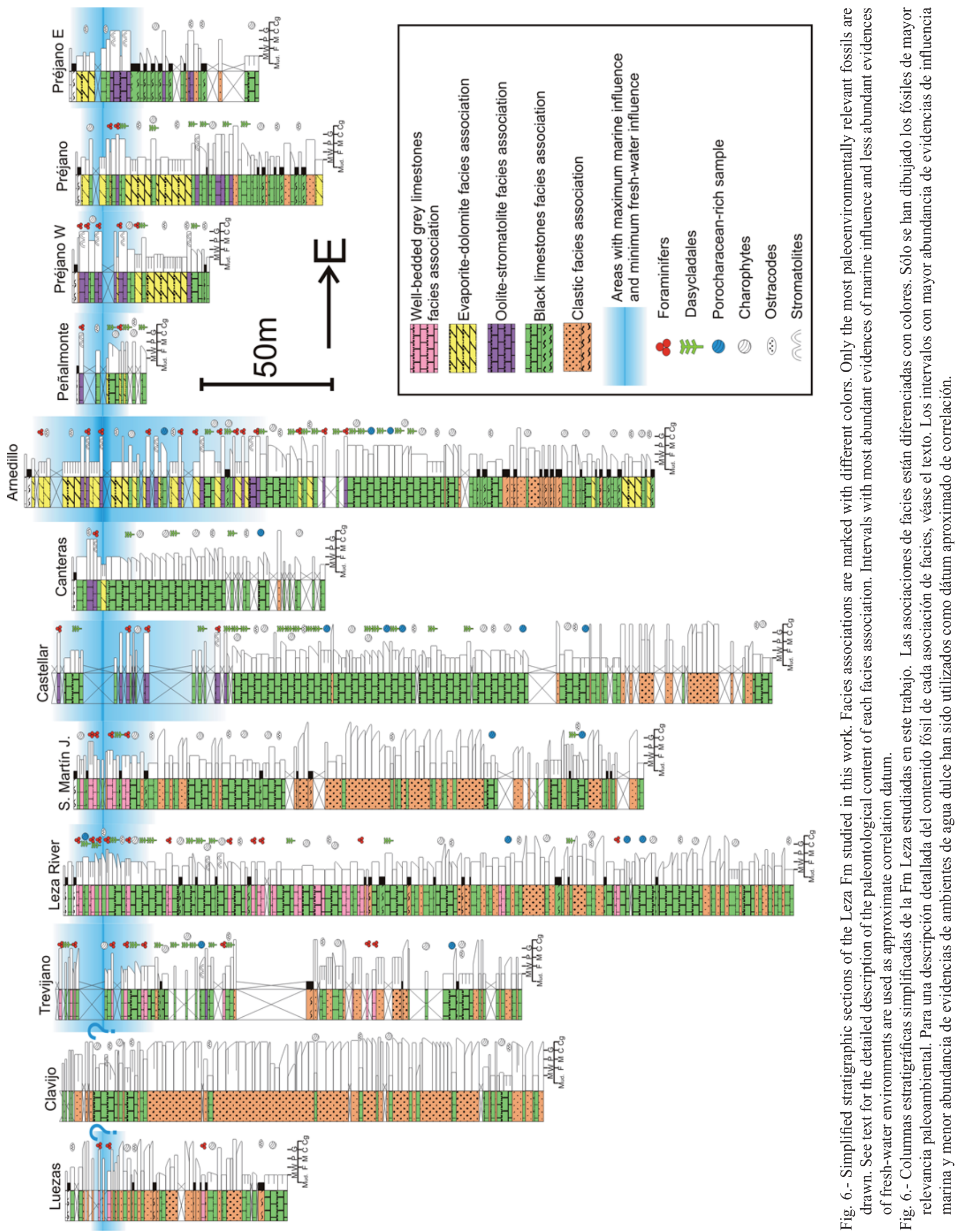

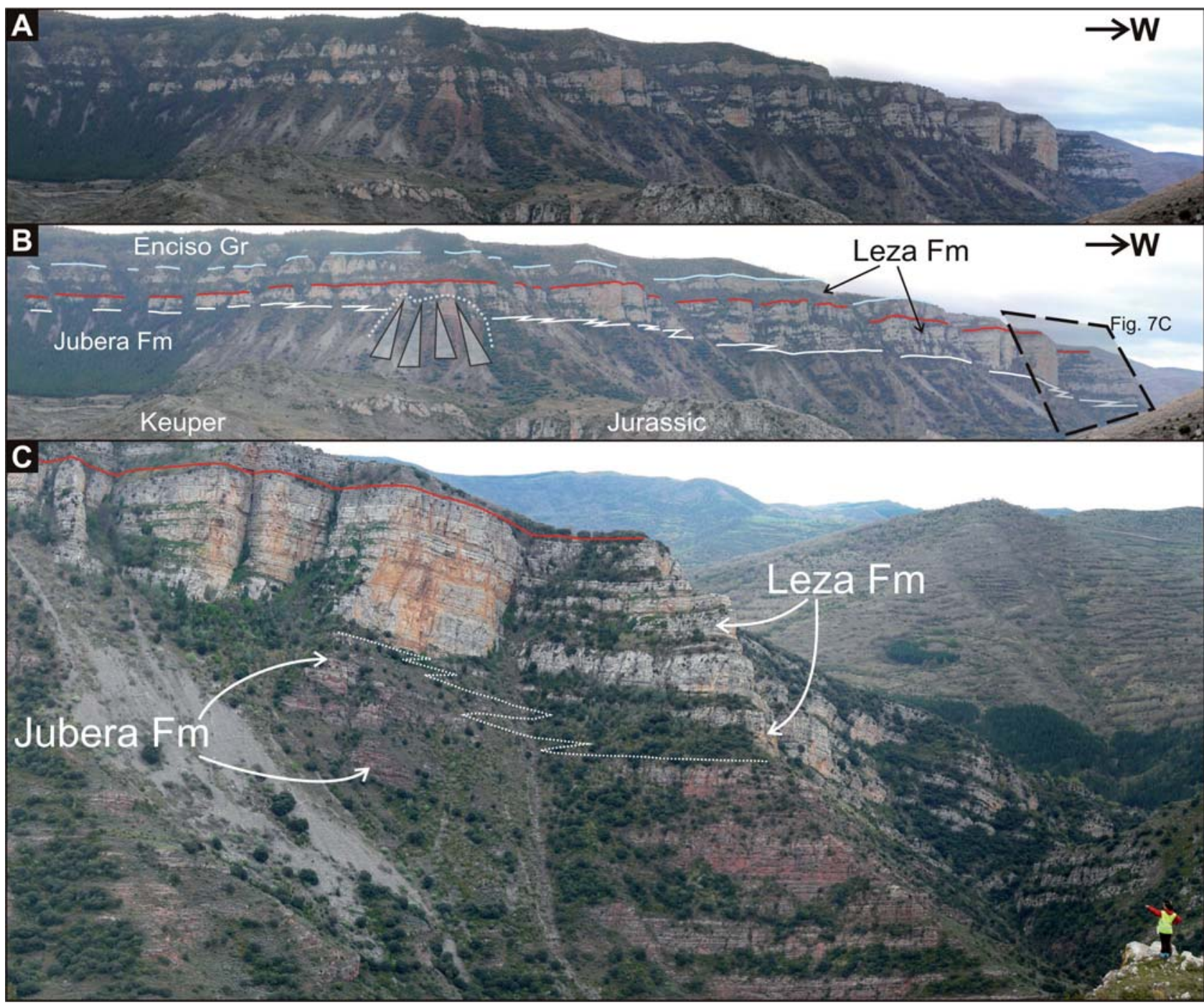

Fig. 7.- A: East-West panoramic view of "Peñas de Leza" seen from the locality of Ribafrecha (see Fig. 3 for exact location). B: Interpretation of A. White line marks the contact between the Jubera Fm and the Leza Fm. Red line highlights a laterally continuous level of the Leza Fm. Blue line marks the contact between the Leza Fm and the Enciso Gr. Note how the Jubera Fm is westward changing to the lower levels of the Leza Fm. In consequence, Leza Fm thins towards the East, where only its upper levels are preserved. C: Detail of the view from A and B, in which the lateral change of facies between Jubera Fm and Leza Fm (dashed white line) is seen at smaller scale. Red line highlights the same level as in B.

Fig. 7.- A: Panorámica este-oeste de las "Peñas de Leza" vistas desde la localidad de Ribafrecha (ver Fig. 3 para la localización exacta). B: Interpretación de A. La línea blanca marca el contacto entre la Fm Jubera y la Fm Leza. La línea roja resalta un nivel de la Fm Leza muy continuo lateralmente. La línea azul marca el contacto entre la Fm Leza y el Gr Enciso. Nótese el paso de la Fm Jubera hacia el oeste a las capas inferiores de la Fm Leza. En consecuencia, la Fm Leza se adelgaza hacia el este, donde sólo se observan sus niveles superiores. C: Detalle de la vista de A y B, en el que se observa a menor escala el cambio lateral de facies entre la Fm Jubera y la Fm Leza (línea blanca punteada). La línea roja marca el mismo nivel resaltado en B.

(Fig. 6), and it occurs in the middle and upper parts of the sections. This facies association contains cross-bedded oolitic grainstones that alternate with less abundant grey mudstones creating flaser, wavy and lenticular beddings (Fig. 10E). Flat-pebble breccias are common. These facies are laterally and vertically related with domal agglutinated oolitic stromatolites (Fig. 10F). Mud-cracks and vertebrate footprints are also observed in this facies association. Grainstones are composed of ooids, peloids, micritic intraclasts and bioclasts (mainly ostracods and benthic miliolid foraminifers, Fig. 10G). Ostracods and foraminifers are also found as trapped particles within the stromatolites. These bioclasts lack any signs of reworking (Fig. 10G) and, therefore, they are considered as in situ remains valid for paleoenvironmental interpretations. This facies association is interpreted to be formed in shallow coastal-lakes, and its characteristic sedimentary structures (flaser, wavy and lenticular beddings) point to tidal influence during its deposition (Suarez-Gonzalez et $a l$. , in press). In addition, the fact that the fossil content is almost restricted to ostracods and foraminifers suggests a somehow anomalous salinity in these coastal-lakes, probably due to a stronger sea-water input than in the black limestones facies association. 
d) The evaporite-dolomite facies association only occurs in the upper part of the eastern sections of the Leza Fm (Fig. 6). It is formed by well-bedded to laminated grey dolomites with abundant pseudomorphs after evaporitic minerals (Figs. 11A, B). Dolomites have dense micritic or peloidal textures. They are poor in fossils, containing scarce ostracods and benthic miliolid foraminifers. The pseudomorphs can be scattered in the matrix (Figs. 11A) or grouped in centimetre-scale laterally-continuous layers (Figs. 11B). Pseudomorphs are variable in size and shape and they grow both displacing and replacing the dolomitic matrix. Morphology of original gypsum and anhydrite are typically observed in the pseudomorphs. Ferruginous surfaces, nodular horizons, mud-cracks and rare teppees structures occur at the top of some beds. This facies association is interpreted as deposited in relatively restricted coastal areas with common influence of sea-water (Suarez-Gonzalez et al., 2010; in press) due to the abundance of pseudomorphs after evaporite minerals and to the scarcity and nature of the fossil content, which suggests that salinity of the original environment was anomalous and/or rapidly changing.

e) The well-bedded grey limestones facies association has been observed in the middle and upper parts of the sections measured on the western outcrops of the Leza Fm (Fig. 6). It is formed by $10-30 \mathrm{~cm}$ thick beds of grey limestones, which typically present mud-cracks and/or vertebrate footprints at their top surfaces. Three different textures are observed in these grey limestones: mudstonewackestones of ostracods and benthic miliolid foraminifers (Fig. 11C, D); packstone-grainstones of peloids, ostracods and foraminifers; and laminated fenestral limestones with micritic, clotted-peloidal and agglutinated microfabrics, as well as relicts of microbial filaments. Small vertical cracks are common in these fenestral limestones, and their fossil content is very low: scattered ostracods and foraminifers, and rare charophytes and dasycladales. Fossils of this facies association lack signs of reworking (Figs. 11C, D). Beds of this facies association are very abundant in the upper part of the unit. They also occur in the middle part (Fig. 6), generally showing a scarcer fossil content. This facies association can be interpreted as being deposited in shallow coastal-lakes with influence of marine water, as indicated by the fossil content. The common mud-cracks and the small vertical cracks preserved in fenestral limestones indicate that desiccation of the coastal-lakes was common.

\subsection{Evidences of marine influence}

Deposits of the Leza Fm contain sedimentological and paleontological evidences of marine influence during their sedimentation. The main sedimentological evidence is the

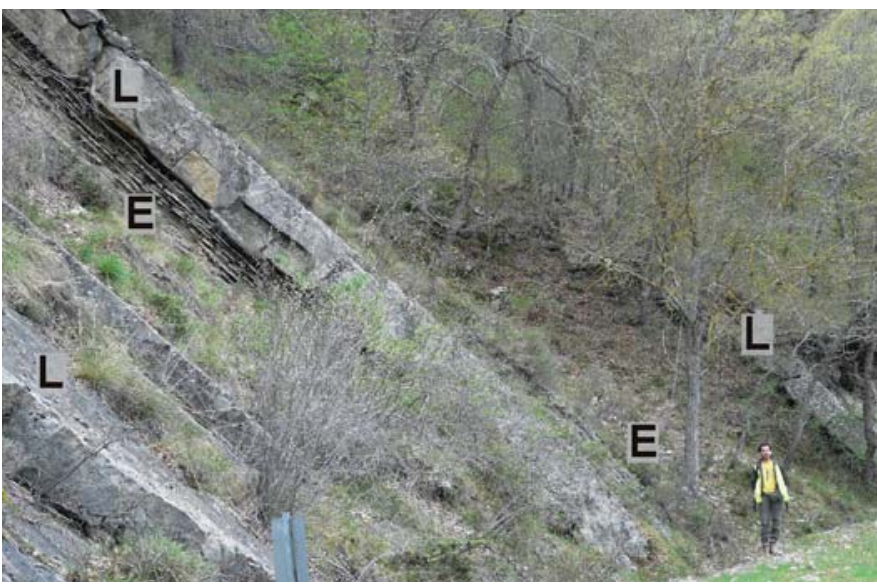

Fig. 8.- Top of the Leza Fm in the Leza River stratigraphic section. Note the alternation between thick limestone beds of the Leza Fm (L) with thin-bedded marls, sandstones and limestones of the Enciso Gr (E). Beds of the Leza Fm thin upwards and eventually disappear.

Fig. 8.- Techo de la Fm Leza en la columna estratigráfica del Río Leza. Nótese la alternancia entre las capas gruesas de caliza de la Fm Leza (L) con las margas, areniscas y calizas tableadas del Gr Enciso (E). Las capas de la Fm Leza se adelgazan progresivamente hacia techo, llegando a desaparecer.

heterolithic alternation of grainy and muddy facies observed in the oolite-stromatolite facies association, which creates sedimentary structures such as flaser, wavy and lenticular beddings (Fig. 10E). These sedimentary structures are characteristic of modern and ancient carbonate tidal environments (see many examples in Ginsburg, 1977; Hardie, 1977; Demicco, 1983; Laseim et al., 2012).

The presence of in situ dasycladales and foraminifers in the Leza Fm deposits (Figs. 10D, 10G, 11C, D) is a clear paleontological indicator of very common marine influence throughout most part of the sedimentation of the unit, since they occur in many successive levels, often alternating with levels only containing fresh-water fossils (Fig. 6). Dasycladales occur in sequences of the black limestones facies association but only in sequences from the middle and upper parts of the studied sections (Fig. 6). A single species of dasycladales has been found in these deposits: Salpingoporella urladanasi (Marc Conrad, Nicolaos Carras and Ioan Bucur, pers. com.). This green alga has a Barremian-Albian stratigraphic range (Carras et al., 2006), and it is usually found in restricted marine, brackish facies, associated with foraminifers, ostracods and charophytes, but also in facies of normal marine salinity (Carras et al., 2006). The paleobiogeography of this species corresponds to the northern Tethyan realm (Fig. 12). In the context of the Iberian Peninsula, S. urladanasi has been confidently described in the Barremian-Aptian of the South-Pyrenean Basin (Peybernès, 1976; Conrad et al., 1977), and in the Albian of Portugal (Rey et al., 1977). According to Carras et al. (2006) it is uncertainly cited in the Basque-Cantabrian Basin (Pascal, 1984). It is cited but not figured in the Asturias area (Dragastan, 


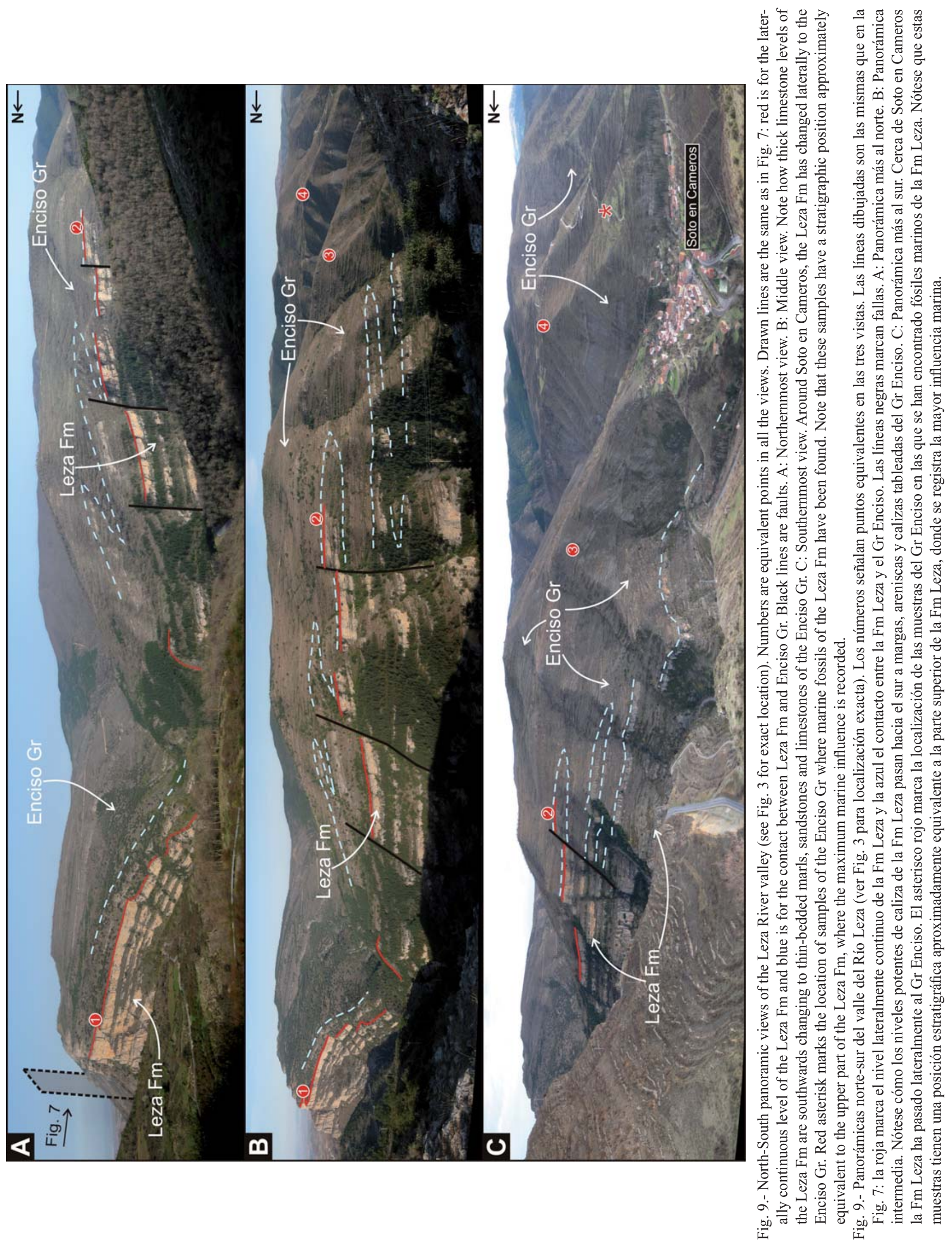


1982), and it has been cited as S. cf. urladanasi and not figured in the Maestrazgo Basin (Canerot et al., 1982).

Foraminifers are also commonly found in situ in the middle and upper parts of the studied sections of the Leza Fm (Fig. 6), but they occur in facies associations different from those of the dasycladales. In fact, samples where dasycladales and foraminifers occur together are extremely rare. This mutual exclusion of dasycladales and foraminifers is further evidence that the Leza Fm was deposited in a complex system with many different paleoenvironments with varying salinities and different degrees of marine influence: facies with dasycladales also commonly include charophytes (Fig. 10D), suggesting fresh-water influence, but facies with foraminifers almost never contain charophytes (Figs. 10G, 11C, D), and many of them show tidal influence (Fig. 10E). Samples with foraminifers occur in the middle and upper parts of the unit, but those found in the middle part typically contain scarce foraminifers. All the foraminifers observed in thin-sections of the Leza Fm belong to the same morphotype of miliolids (Figs. 10G, 11C, D), which presents the characteristic features of the genus $I s-$ triloculina (Esmeralda Caus, pers. com.). This genus is Early Cretaceous in age (Loeblich and Tappan, 1988) and it has been described in localities such as the Southern Pyrenees (Bernaus et al., 2002; 2003), Portugal (Lezin et al., 2010), SE France (Arnaud-Vanneau, 1980; Masse et al., 2003), Croatia (Márton et al., 2010), Romania (Neagu, 1984), Bulgaria (Iovcheva, 1962), and Turkey (Masse et al., 2009). Istriloculina is typically found in shallow, restricted environments with anomalous salinities, and commonly associated with ostracods, dasycladales and charophytes.

Charophytes of the black limestones facies association are also an important source of paleoenvironmental information. They belong to the families Clavatoraceae and Porocharaceae (Carles Martín-Closas, pers. com.). Specimens of both families can be found together in the same sample but some sequences of the lower and middle parts of the studied sections contain charophytes assemblages mostly dominated by porocharacean gyrogonites. The presence of homogeneous populations of porocharacean remains in Lower Cretaceous deposits is an indicator of brackish paleoenvironments (Martín-Closas and Grambast-Fessard, 1986; Mojon, 1989; Schudack, 1993), and they have been found associated with dasycladales and benthic foraminifers (Climent-Domenech et al., 2009). Therefore, these porocharacean assemblages of the Leza Fm can be considered as further evidence of the influence of marine water during the deposition of this unit.

For this study, we have also re-examined the microfossil content of the Enciso Gr facies in the area surrounding Soto en Cameros, where these facies are laterally changing to those of the Leza Fm (Fig. 3, 8C), and we have found previously unrecorded marine microfossils (dasycladales and foraminifers) in two levels of the Enciso Gr close to Soto en Cameros (Fig. 8C). These microfossils (Fig. 11E, F) are identical to those of the Leza Fm (Figs. 10C, 10G, 11C, D) and, interestingly, they have been found in levels stratigraphically correlatable with the uppermost part of the Leza River section of the Leza Fm (Fig. 9), where marine microfossils are most abundant (Fig. 6).

\section{Discussion}

\subsection{Tectonic control of the Leza Fm and relationships with adjacent units}

Sedimentation of the Jubera Fm and the Leza Fm was tectonically controlled, since these units crop out in a series of independent fault-bounded lithosomes with smaller-scale faults that control the thickness of the units (Figs. $3,4)$. When the geographic distribution of these lithosomes and the measured thicknesses of the Jubera and Leza Fms are represented together in a correlation panel (Fig. 13) the influence of synsedimentary faults in the distribution and thickness of both units is clearly noticeable.

Given the facies associations described in Section 4.2, the Leza Fm can be interpreted as deposited in a system of coastal wetlands mainly formed by shallow carbonate water-bodies separated by flat palustrine areas (Suarez-Gonzalez et al., 2010; 2012; in press). These coastal wetlands were laterally related to the clastic deposits of the Jubera Fm (Fig. 7), attributed to alluvial fans with their main source areas located on the Jurassic carbonate substrate of the basin (Alonso and Mas, 1993). This stratigraphic relationship between alluvial fans and more distal lacustrine, coastal or marine deposits is characteristic of small tectonic depressions (i.e. grabens or halfgrabens) from the active margins of modern and fossil rift basins (Leeder and Gawthorpe, 1987; Gawthorpe et al., 1997; Gawthorpe and Leeder, 2000).

The coastal wetlands of the Leza Fm were related to the south (central area of the Cameros Basin) with deposits of the Enciso Gr (Fig. 8), which have been interpreted as wide fluvial and shallow lacustrine areas with carbonate precipitation and strong siliciclastic influence (AlonzoAzcárate, 1997; Alonso-Azcárate et al., 1999; Doublet et al., 2003; Doublet, 2004), with main paleocurrent directions to the NE (Mas et al., 1993). Thus, the lateral facies change between the Enciso Gr facies and the Leza Fm (Fig. 8) indicates a progradation of the fluvio-lacustrine Enciso Gr over the more distal Leza Fm coastal wetlands.

All these tectonic and stratigraphic data show that the Jubera Fm, the Leza Fm and the Enciso Gr belong to the 
same depositional sequence. During this sequence, extensional stresses produced fracturing of the Cameros Basin substrate on its northern margin, creating small depressions arranged in a NW-SE distribution. In these depressions, fault-scarps and associated erosion of the fractured substrate generated alluvial fan deposits (Jubera Fm) laterally related with distal coastal wetlands (Leza Fm). In turn, these coastal wetlands passed gradually towards the centre of the basin to a broad fluvio-lacustrine system (Enciso Gr) (Fig. 14).

\subsection{Eustatic control of the Leza Fm}

Our detailed stratigraphic and sedimentological study of the Leza Fm shows that marine influence during sedimentation of the unit is stronger than previously suggested (Guiraud, 1983; Guiraud and Seguret, 1985; Alonso and Mas, 1993). In fact, the common occurrence of levels with evidences of marine influence and their interfingering with levels that do not contain any of those evidences (Fig. 6) suggests that, during the sedimentation of the Leza Fm, water-bodies with sea-water input coexisted laterally with water-bodies mainly filled with freshwater, as it is typically observed in present-day coastal systems (Gebelein, 1977; Hardie, 1977; Platt and Wright, 1992; Reed, 2002). Furthermore, the main paleontological evidences of marine influence in the Leza Fm carbonates are assemblages of dasycladales and foraminifers with extremely low diversity but high abundance, which is a common situation in stressful environments (Brenchley and Harper, 1998). In the context of the Leza Fm, this biotic stress could have been easily produced by changes in salinity, as it occurs in modern coastal systems, either due to decreasing salinity by mixture of waters, or to increasing salinity by restriction and evaporation (Hardie, 1977; Waterkeyn et al., 2008). These changes in salinity in the Leza Fm are supported by the presence of brackish-water charophytes and pseudomorphs after evaporite minerals.

Evidences of marine influence are not randomly distributed in the stratigraphic sections of the Leza Fm (Fig. 6). Although some of the sections present different distribution of facies, evidences of marine influence show the same trend in most of them (Fig. 6):

a) The lower part of the sections is dominated by clastic deposits with very little marine influence: some samples rich in porocharaceans, and scattered samples with few foraminifers in the western area.

b) In the middle part of the section, samples with dasycladales start to be very common, alternating with samples containing porocharaceans, samples without marine influence, and less common samples with foraminifers. In the eastern outcrops, facies with tidal influence also start to be abundant at the middle part of the sections.

c) Towards the upper part of the sections, samples with foraminifers start to be more abundant. In the eastern outcrops, facies with tidal influence occur, but evaporitic facies, also containing foraminifers, predominate. Evaporitic facies have not been found in the western outcrops. Moreover, samples without any evidence of marine influence are especially rare in the upper part of the Leza Fm.

This general vertical trend is found in most of the measured stratigraphic sections of the Leza Fm (Fig. 6), which suggests that sedimentation of the unit was somehow controlled by eustasy, showing a transgressive evolution, from: a) a system dominated by alluvial environments and freshwater to brackish carbonate lakes; to $b$ ) a system

Fig. 10.- (next page) Photographs of characteristic facies of the Leza Fm. A: Outcrop of the clastic facies association. Poorly sorted conglomerates mainly composed of lithoclasts of Jurassic limestone in a sandy matrix. Clavijo section. B: Thickening-upwards sequences of the black limestones facies association. Castellar section. C: Upper part of a sequence of the black limestones facies association showing root traces associated with a brecciated horizon that thins and disappears towards the right. Préjano section. D: Photomicrograph of a wackestone of dasycladales (white arrows) from the black limestones facies association. Ch: charophyte. Sample from the Trevijano section. E: Detail of oolitic facies of the oolite-stromatolite facies association. Note alternation of grainstone layers (dark grey) with mudstone layers (light grey). Mudstone layers may include lenses of rippled grainstone (white arrows), creating lenticular bedding. Préjano East section. F: Outcrop view of the oolite-stromatolite facies association, in which a domical agglutinated oolitic stromatolite (red dashed line) is onlapped by layers of ooid grainstone (yellow lines). Rock hammer for scale. Canteras section. G: Photomicrograph of a peloidal grainstone from the oolite-stromatolite facies association, showing the characteristical fossil content of this facies association: ostracods and miliolid foraminifers (white arrows). Sample from the Préjano West section.

Fig. 10.- (página siguiente) Fotografías de facies características de la Fm Leza. A: Alforamiento de la asociación de facies clástica. Conglomerados mal seleccionados compuestos principalmente por litoclastos de caliza Jurásica en una matriz arenosa. Columna de Clavijo. B: Secuencias estratocrecientes de la asociación de facies de calizas negras. Columna de Castellar. C: Parte superior de una secuencia de la asociación de facies de calizas negras mostrando huellas de raíces asociadas con un nivel brechificado que se adelgaza y desaparece hacia la derecha. Columna de Préjano. D: Imagen al microscopio de un wackestone de dasycladales (flechas blancas) de la asociación de facies de calizas negras. Ch: carofita. Muestra de la columna de Trevijano. E: Detalle de las facies oolíticas de la asociación de facies oolitico-estromatolítica. Nótese la alternancia de niveles grainstone (gris oscuro) con niveles mudstone (gris claro). Los niveles mudstone pueden contener lentículas de grainstone con ripples (flechas blancas) creando estratificación lenticular. Columna de Préjano Este. F: Imagen de afloramiento de la asociación de facies oolítico-estromatolítica, en la que se observa un domo de estromatolito aglutinante oolítico (línea roja discontínua) sobre el que se apoyan capas de grainstone oolítico (líneas amarillas). Martillo como escala. Columna de Canteras. G: Imagen de microscopio de un grainstone peloidal de la asociación de facies oolítico-estromatolítica, en la que se observa el contenido fósil característico de esta asociación de facies: ostrácodos y miliólidos (flechas blancas). Muestra de la columna de Préjano Oeste. 

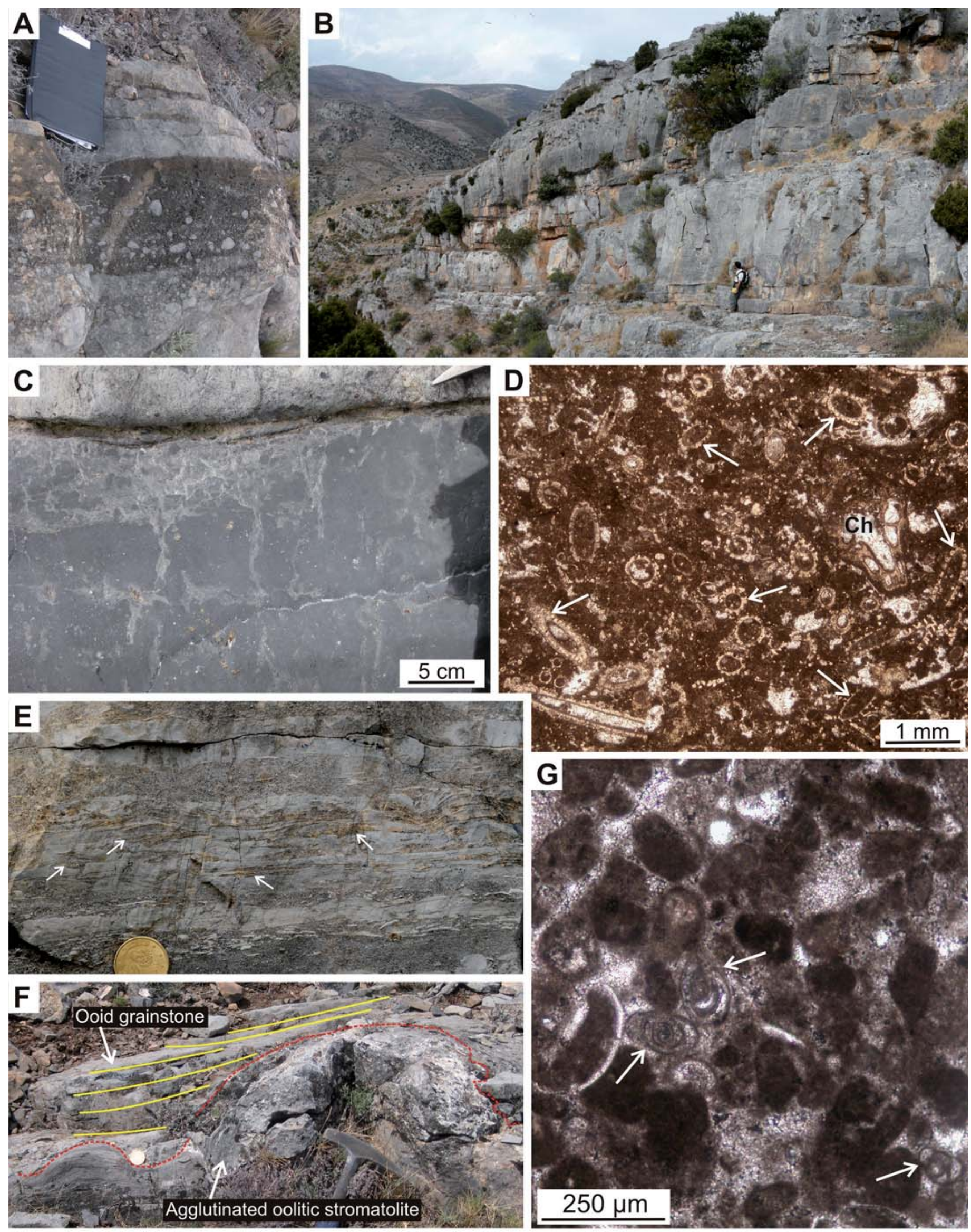
of coastal-lakes and wetlands with clear marine influence (abundance of dasycladales) but with fresh-water influence still noticeable (common presence of charophyterich facies); ending with $c$ ) a similar system of coastal wetlands, in which coastal-lakes containing ostracods and foraminifers were more common. In the eastern sector, many of these coastal-lakes were influenced by tides, and others were relatively restricted, allowing precipitation of evaporite minerals, such as gypsum and anhydrite.

\subsection{Age of the Leza Fm and correlation with marine basins}

The new data presented here, concerning marine influence in the Leza Fm and its relationship with Jubera Fm and Enciso Gr can shed light on the controversial age of these units (see Section 2.1). Geological mapping and stratigraphic data show that the Leza Fm is genetically related with the Jubera Fm (Fig. 3, 4, 7), and that it changes laterally to the Enciso Gr (Fig. 8), thus being part of it, as it was originally described by Tischer (1966) and has subsequently been recognized by different authors (see Section 2.1 and Fig. 5). Furthermore, the paleontological data presented here support the assignment of an upper Barremian-lower Aptian age for the Enciso Gr, as proposed by Mas et al. (1993) and Martín-Closas and Alonso (1998), since the dasycladales (Salpingoporella urladansi) found in the Leza Fm and in the Enciso Gr facies have a Barremian-Albian distribution (Carras et al., 2006), and the foraminifers found in both units (cf. Istriloculina) have a Berriasian-Aptian distribution, but are most commonly cited in Barremian-Aptian deposits (Iovcheva, 1962; Neagu, 1984; Bernaus et al., 2002; Masse et al., 2003; 2009). The alternative dating that has been proposed for the Leza Fm considers it as part of the Oncala Gr, Berriasian in age (see Section 2.1 and Fig. 5), but this attribution is not supported by stratigraphic, sedimentological and paleontological results presented herein. Furthermore, detailed sedimentological studies of the Oncala Gr (Quijada et al., 2010; 2013; in press; this volume) clearly show that its facies and sedimentary evolution differ significantly from those observed in the Leza Fm. Therefore, both the Jubera and Leza Fms are part of Depositional Sequence 7 (DS7) of Mas et al. (2002a), upper Barremian-lower Aptian in age (Fig. 2). Given this age and given the transgressive trend described in the Leza Fm (see section 5.2), a higher chronostratigraphic resolution might be obtained for this unit by comparison with eustatic trends of neighbouring marine basins and with global eustatic curves.

A general trend of rising sea-level is widely recognized from the late Barremian to the early Aptian, resulting in the established view that the early Aptian is an essentially transgressive period (Tyson and Funnell, 1987; Ruffell, 1991; Sahagian et al., 1996; Mutterlose, 1998; Huang et al., 2010). This transgressive trend is also apparent in the marine basins closest to the Cameros Basin: the BasqueCantabrian Basin (García-Mondéjar, 1990; Wilmsen, 2005; García-Mondéjar et al., 2009; Najarro et al., 2011); the Iberian Basin (Canerot et al, 1982; Vilas et al, 1983; Soria et al., 1992; Salas and Martín-Closas, 1995; BoverArnal et al., 2003; Moreno-Bedmar et al, 2009; Peropadre, 2012); and the Pyrenean Basin (Peybernès, 1976; Rosell and Llompart, 1982; García-Senz, 2002; Bernaus et al., 2003). The exact chronostratigraphic position of the transgressive-regressive cycles defined in these basins depends on the location, methodology and resolution of the study and, therefore, the age of the maximum peak of late Barremian-early Aptian sea-level differs slightly in some of the aforementioned works on marine basins from northern and eastern Iberia. However, the transgressive peak is, in general, placed at some point of the two middle ammonite biozones of the early Aptian, Deshayesites forbesi (also referred to as D. weissi) and Deshayesites deshayesi biozones (García-Senz, 2002; Bernaus et al., 2003; Bover-Arnal et al., 2003; Willmsen, 2005; GarcíaMondéjar et al., 2009; Moreno-Bedmar et al, 2009; Najarro et al., 2011; Peropadre, 2012). This is consistent with most of the age data for the maximum sea-level dur-

Fig. 11.- (next page) Photogaphs of characteristic facies of the Leza Fm. A: Upper surface of a bed of the evaporite-dolomite facies association with abundant pseudomorphs after lenticular gypsum (orange arrows). Préjano section. B: Beds of the evaporite-dolomite facies association showing thin levels composed of very abundant small pseudomorphs after evaporite minerals. Préjano section. C: Photomicrograph of a characteristic microfacies of the well-bedded grey limestones facies association, wackestone-packstone of ostracods and miliolid foraminifers. Sample from the Trevijano section. D: Detail of the same sample as C. E: Photomicrograph of a sample of the Enciso Gr collected close to Soto en Cameros (see Fig. 9C for exact location), which contains the same dasycladales as the Leza Fm. F: Photomicrograph of a sample of the Enciso Gr collected close to Soto en Cameros (see Fig. 9C for exact location), which contains the same miliolid foraminifers as the Leza Fm.

Fig. 11.- (página siguiente) Fotografías de facies características de la Fm Leza. A: Techo de una capa de la asociación de facies de evaporitas y dolomías, con abundantes pseudomorfos de yeso lenticular (flechas naranjas). Columna de Préjano. B: Capas de la asociación de facies de evaporitas y dolomías, con algunos niveles finos formados por pequeños pseudomorfos de minerales evaporíticos muy abundantes (flechas naranjas). Columna de Préjano. C: Imagen de microscopio de una microfacies característica de la asociación de facies de calizas grises tableadas, wackestone-packstone de ostrácodos y miliólidos. Muestra de la columna de Trevijano. D: Detalle de la misma muestra de C. E: Imagen de microscopio de una muestra del Gr Enciso tomada en las proximidades de Soto en Cameros (ver Fig. 9C para la localización exacta), que contiene las mismas dasycladales que la Fm Leza. E: Imagen de microscopio de una muestra del Gr Enciso tomada en las proximidades de Soto en Cameros (ver Fig. 9C para la localización exacta), que contiene los mismos foraminíferos que la Fm Leza. 

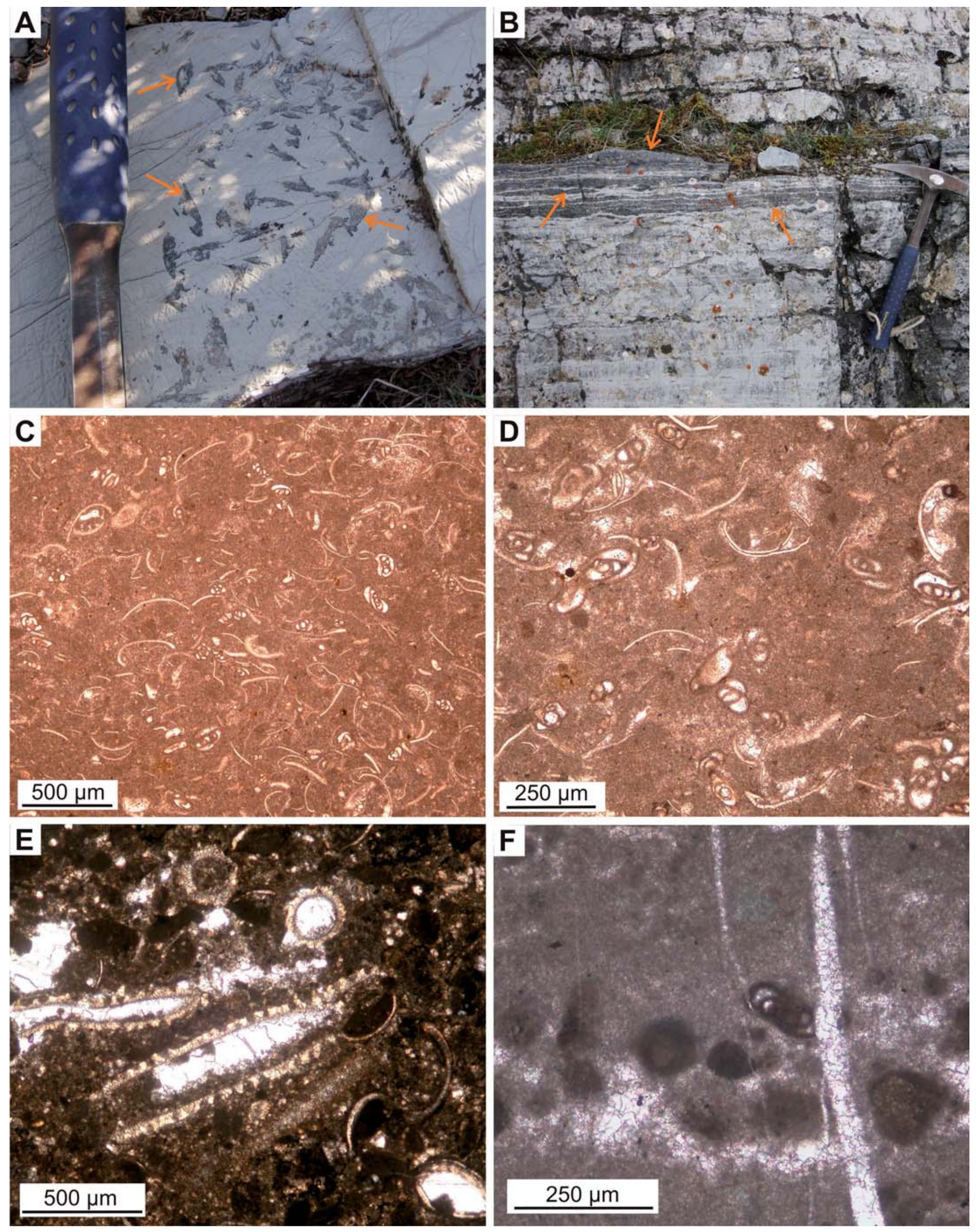


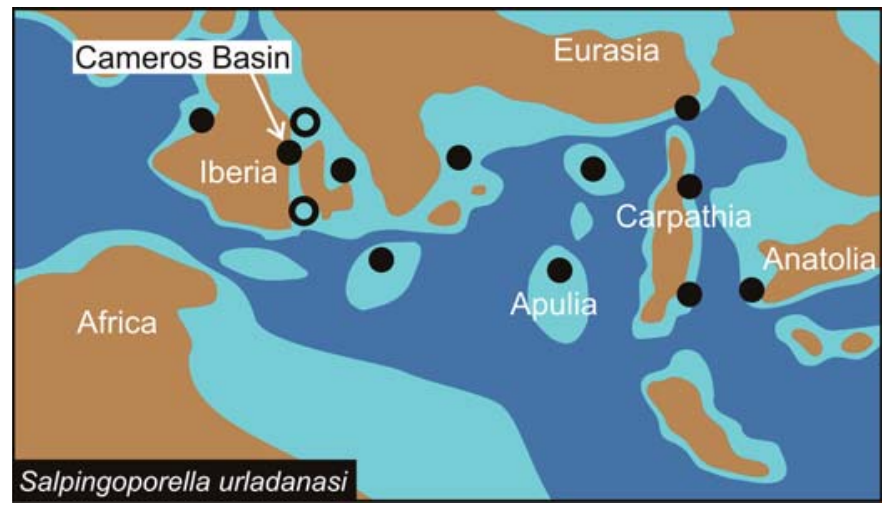

Fig. 12.- Paleogeographic distribution of published occurrences of Salpingoporella urladanasi. Full circles show contrasted occurences and empty circles show uncertain occurrences. Data are taken from Carras et al. (2006), plus non-figured occurrences of the Basque-Cantabrian (Dragastan, 1982) and Iberian Basins (Canerot et al., 1982). Paleogeographic reconstruction for the Aptian is redrawn after Ziegler (1988), Hay et al. (1999), Masse et al. (2000), the reconstruction of Ronald Blakey, available at http://www2.nau.edu/rcb7, and our own compilation of data for the Iberian Peninsula (Fig. 15). Note that, although the paleogeographic reconstruction is for the Aptian, occurrences of S. urladanasi may be from different or uncertain ages, since its stratigraphic range is Barremian-Albian.

Fig. 12.- Distribución paleogeográfica de las citas publicadas de Salpingoporella urladanasi. Los círculos rellenos muestran citas contrastadas y los círculos vacíos citas inciertas. Datos tomados de Carras et al. (2006), y de citas no figuradas de la cuencas Vasco-Cantábrica (Dragastan, 1982) e Ibérica (Canerot et al., 1982). La reconstrucción paleogeográfica para el Aptiense está redibujada a partir de Ziegler (1988), Hay et al. (1999), Masse et al. (2000) ), la reconstrucción de Ronald Blakey, disponible en http://www2.nau.edu/rcb7, y nuestra propia recopilación de datos para la Península Ibérica (ver Fig. 15). Nótese que, pese a que la reconstrucción paleogeográfica es para el Aptiense, las citas de S. urladanasi pueden ser de edad diferente o incierta, ya que su rango estratigráfico es Barremiense-Albiense.

ing the same period in other Tethyan and North Atlantic basins (Arnaud-Vanneau and Arnaud, 1990; Jacquin et al., 1998 and references therein; Haq and Al-Qahtani, 2005; Bachmann and Hirsch, 2006; Masse and Fenerci Masse, 2011). Therefore, the transgressive peak of the middle-upper part of the early Aptian can be regarded as a widespread eustatic maximum.

\subsection{Eustatic vs. Tectonic control}

Rift basins located in coastal or marine settings challenge recognition of the relative roles of tectonics and eustasy in the generation of accommodation space (Lambeck et al., 1987; Ravnas and Steel, 1998; Miall and Miall, 2001; De Benedictis et al., 2007). In the case of the Leza Fm, the role of tectonics is shown by its deposition in a series of small fault-controlled depressions (Figs. 3, $4,13)$. The amount of accommodation space generated by tectonics was different in each depression, as shown by changes of maximum thicknesses, facies and vertical distribution of facies from one lithosome to the other (Figs.
$6,13)$. In spite of these changes, the same transgressive trend is observed in sections of all tectonic depressions (Fig. 6, see section 5.2), which points to an additional eustatic control on the sedimentation of the unit.

Faults on the Jurassic substrate of the Cameros Basin created accommodation space, in which a proximal system of alluvial fans and a distal system of coastal wetlands were deposited (Fig. 14). During sedimentation of the lower part of the Leza Fm, clastic facies, dominated by lithoclasts of the Jurassic substrate, were very abundant, indicating that this substrate was being eroded, probably due to active creation of relief by fault movement. In addition, the lower part of the Leza Fm contains very rare evidences of marine influence, which suggests that the wetlands were dominated by fresh-water input. Towards the upper part of the Leza Fm clastic facies are less abundant (Fig. 6). One possible explanation for this is that fault movement was attenuated. However, sections of the Leza Fm located in marginal areas of the lithosomes, such as Clavijo and Luezas sections (Fig. 6), contain very abundant clastic facies even in upper parts of the unit, suggesting that fault-scarps were also being generated and eroded in late stages of sedimentation of the Leza Fm. In addition, evidences of marine influence are progressively more abundant upwards, and Figure 7 shows that while lower levels of the Leza Fm are rapidly changing laterally to the Jubera Fm, the upper levels (those with maximum marine influence, Fig. 6) are much more extensive, reaching even the fluvio-lacustrine sediments of the Enciso Gr (Fig. 8). These data suggest that a rising sea-level during the middle-upper part of the early Aptian created additional accommodation space for the sedimentation of the upper part of the Leza Fm. This allowed the deposits of the unit to spread extensively towards the borders of the tectonic depressions, and even towards the South, to more proximal areas of the Cameros Basin. This provides a suitable hypothesis to the progressive reduction of clastic facies generally observed in the upper part of the Leza.

Therefore, we interpret that the upper part of the Leza $\mathrm{Fm}$, where the strongest marine influence is recorded, might be correlated with the two middle biozones of the early Aptian, in which the transgressive peak is generally found (see section 5.3 above).

\subsection{Paleogeographic context of the Leza Fm: the early Aptian of NE Iberia}

During the early Aptian, the eastern Cameros Basin had a clear Southwest-Northeast paleogeographical distribution of sedimentary environments (Mas et al., 2011): from siliciclastic fluvial systems on the Southwest (uppermost Urbión Gr, Fig. 2), to mixed siliciclastic-car- 


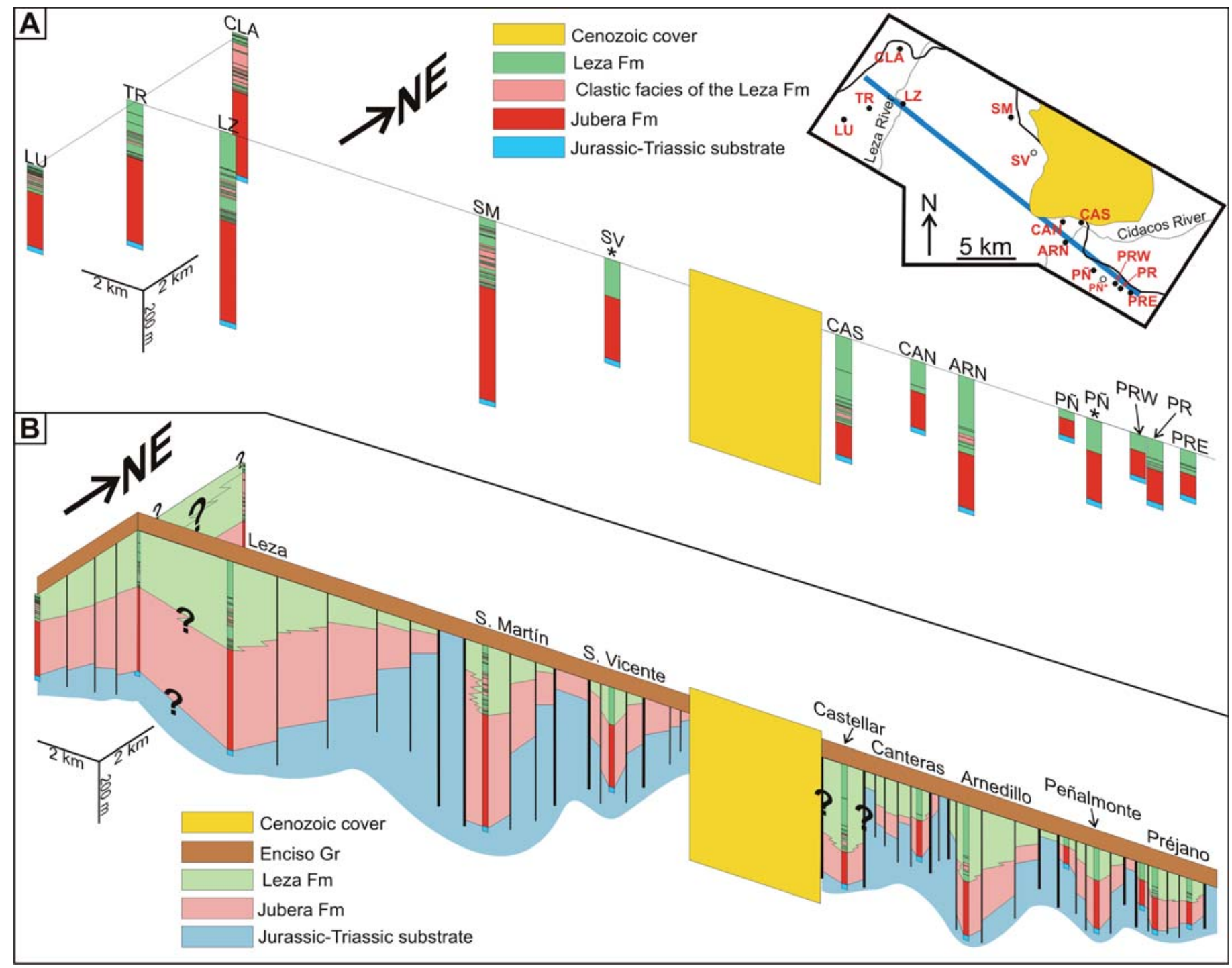

Fig. 13.- Correlation panel of stratigraphic sections of the Leza and Jubera Fms. A: Panel with the stratigraphic sections. On the upper right a small map shows location of the sections and of the correlation line (blue). The top of the Leza Fm has been used as correlation datum. Thicknesses of the Jubera Fm are taken from Ochoa (2006), Hernández Samaniego et al. (1990), and from our own measurements. Stratigraphic sections marked with asterisk were not logged with detail, but just measured. LU: Luezas. TR: Trevijano. CLA: Clavijo. LZ: Leza River. SM: San Martín de Jubera. SV: San Vicente de Jubera. CAS: Castellar. CAN: Canteras. ARN: Arnedillo. PÑ: Peñalmonte. PRW: Préjano West. PR: Préjano. PRE: Préjano East. B: The stratigraphic sections of A have been correlated using data from geological mapping. The eight fault-bounded lithosomes of the Leza Fm are clearly seen, divided in two areas separated by a Cenozoic outcrop.

Fig. 13.- Panel de correlación de las columnas estratigráficas de las Fms Leza y Jubera. A: Panel con las columnas estratigráficas. Arriba a la derecha un mapa muestra la situación de las columnas y de la línea de correlación (azul). El techo de la Fm Leza ha sido utilizado como dátum de correlación. Los espesores de la Fm Jubera están tomados de Ochoa (2006), Hernández Samaniego et al. (1990), y de nuestras propias medidas. Las columnas estratigráficas marcadas con un asterisco no han sido levantadas con detalle, sino simplemente medidas. LU: Luezas. TR: Trevijano. CLA: Clavijo. LZ: Leza River. SM: San Martín de Jubera. SV: San Vicente de Jubera. CAS: Castellar. CAN: Canteras. ARN: Arnedillo. PÑ: Peñalmonte. PRW: Préjano Oeste. PR: Préjano. PRE: Préjano Este. B: Las columnas estratigráficas de A han sido correlacionadas usando los datos de la cartografía geológica. Se pueden diferenciar claramente los ocho litosomas de la Fm Leza limitados por fallas, divididos en dos grandes áreas separadas por un afloramiento cenozoico.

bonate fluvio-lacustrine plains (Enciso Gr, Fig. 2), and finally to carbonate marine-influenced coastal-wetlands on the Northeast (Leza Fm, Figs. 2, 8). The northeasternmost margin of the basin was marked by fault-scarps on the Jurassic substrate, which was the main source area of a system of alluvial fans (Jubera Fm, Fig. 2) that were laterally related to the coastal-wetlands of the Leza Fm (Fig. 7). Further to the north, outside the Cameros Basin, there was an area of none to very low subsidence, part of the Ebro Massif, with small subsiding depressions interpreted to be associated with the extension of the Cameros Basin (Mas et al., 2002b; 2004). In order to establish the paleogeographic context of the Cameros Basin during this period, Figure 15A presents a new detailed compilation of outcrop and borehole data (see section 3 for bibliographical details) concerning the early Aptian record 


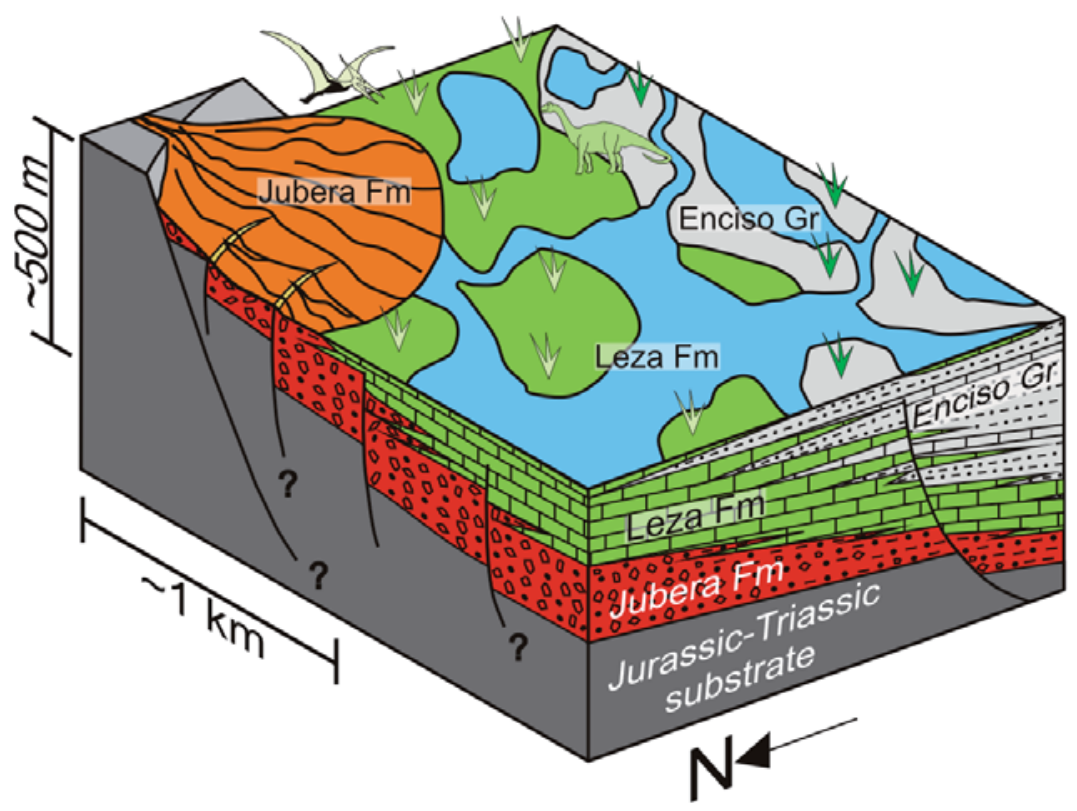

Fig. 14.- 3D diagram showing the stratigraphic and paleogeographic relationships between the Jubera Fm, the Leza Fm and the Enciso Gr. The diagram represents the sedimentation of the upper part of the Leza Fm, where the maximum marine influence is recorded, reaching the Enciso Gr.

Fig. 14.- Bloque diagrama que muestra las relaciones estratigráficas y paleogeográficas entre la Fm Jubera, la Fm Leza y el Gr Enciso. El diagrama representa la sedimentación de la parte superior de la Fm Leza, en la que se registra la máxima influencia marina, que llega hasta el Gr Enciso. of sedimentary basins from Northern and Eastern Iberia.

The marine influence observed in the Leza Fm has been typically considered as coming from the Iberian Basin, to the SE of the Cameros Basin (Alonso and Mas, 1993; Mas et al, 2004; Suarez-Gonzalez et al., 2010; Mas et al., 2011), due to the Tethyan affinity of Salpingoporella. urladanasi (Carras et al., 2006) and to the fact that the Cameros Basin is part of the Iberian tectonosedimentary rift system (Mas et al., 1993; Guimerà et al., 1995; Salas et al., 2001). The northernmost limit of the early Aptian transgression for the Iberian Basin is located just to the
Southeast of the Cameros Basin (Fig. 15A), close to the town of Ciria (Soria), in an outcrop of ostreid-rich coastal siliciclastic sediments (Alonso and Mas, 1988; Mas et al., 2011; Sacristán-Horcajada et al., 2012). However, the marine Aptian outcrop closest to the Leza Fm is located at the northeastern margin of the Cameros Basin (Fig. $15 \mathrm{~A}$ ), close to the town of Grávalos (La Rioja), and it is part of the strongly thinned footwall succession of the basin (Mas et al., 2011). This outcrop contains bioclastic limestones with abundant rudists, foraminifers, green and red algae, and echinoderms (Muñoz et al., 1997; Arribas

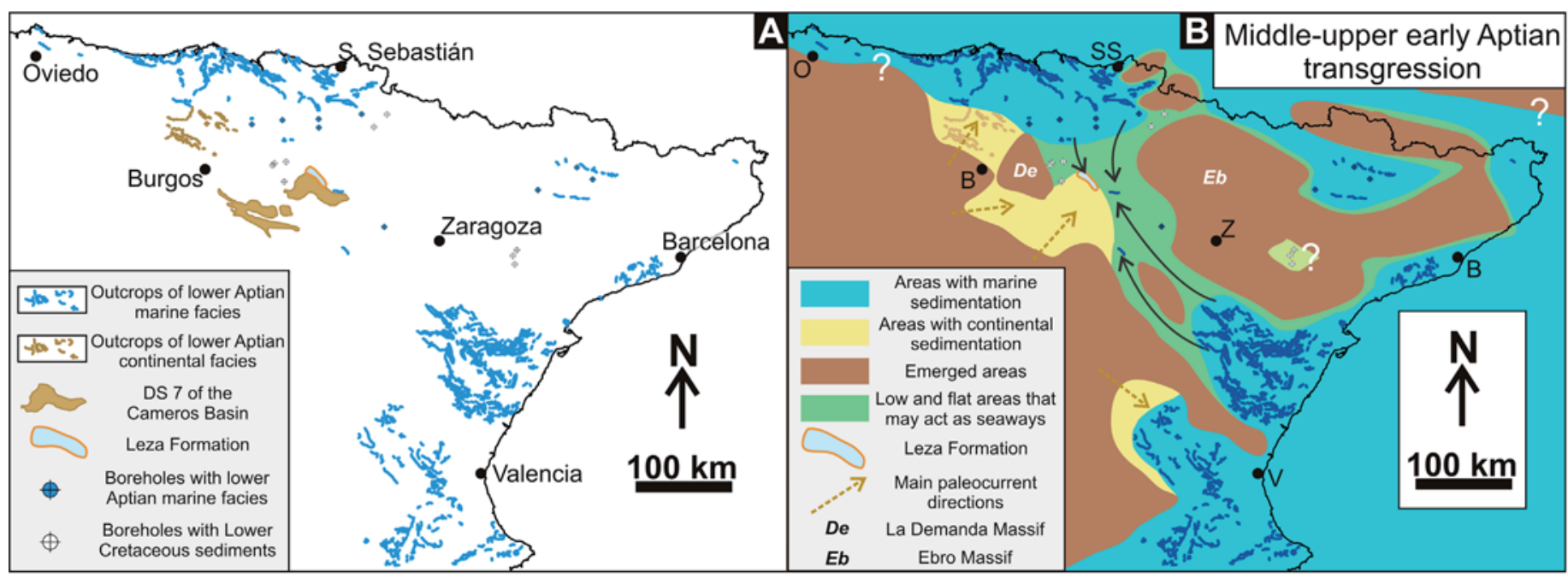

Fig. 15.- Paleogeography of NE Iberia during the marine transgression of the middle-upper part of the early Aptian. A: Occurrences of lower Aptian rocks, from outcrop and boreholes, in NE Iberia. Boreholes with undetermined Lower Cretaceous are also drawn. (See section 3 - Methods for details on the sources of the data). B: Paleogeographic interpretation using the data shown in A, as well as previous reconstructions (see section 3 - Methods for references used).

Fig. 15.- Paleogeografía del NE de Iberia durante la transgresión marina de la parte media-superior del Aptiense inferior. A: Presencia de rocas del Aptiense inferior, en afloramiento y en sondeos, en el NE de Iberia. Sondeos con Cretácico Inferior indeterminado también han sido dibujados. (Ver el apartado 3 - Methods para detalles sobre las fuentes de los datos). B: Interpretación paleogeográfica usando los datos de A, así como reconstrucciones previas (ver en la sección 3 - Methods las referencias usadas). 
et al., 2009; Rodríguez Quiroga, 2011). An early Albian age has been assigned to this Grávalos ouctrop (Muñoz et al., 1997) but, according to other interpretations, it is more likely to be early Aptian in age, since it is overlaid by sediments of the upper Aptian-lower Albian depositional sequence (Arribas et al, 2009; Mas et al, 2011; Rodríguez Quiroga, 2011). Therefore, this early Aptian shallow marine area was very likely to be connected to the coastal-wetlands of the Leza Fm (Fig. 15A). The Grávalos ouctrop has been paleogeographically assigned to the northern Basque-Cantabrian Basin (Muñoz et al., 1997), but also to the southeastern Iberian Basin (Arribas et al, 2009; Mas et al, 2011; Rodríguez Quiroga, 2011). It is clearly established that the early Aptian transgression coming from the Iberian Basin reached areas located on the SE of the Cameros Basin, such as the Ciria outcrop (Alonso and Mas, 1988) but, since the Grávalos outcrop is approximately equidistant from the Ciria outcrop and from abundant marine facies of the Basque-Cantabrian Basin, a northern source of marine influence should not be ruled out.

The Basque-Cantabrian Basin shows a very similar distribution of paleoenvironments to that of the Cameros Basin, with continental facies on the Southwest passing to marine facies to the Northeast (Fig. 15A). For the early Aptian, the Cameros Basin and the Basque-Cantabrian Basin were separated by La Demanda Massif (Fig. 15B), which was an emerged land since Kimmeridgian times (Alonso et al., 1986-1987; Benito and Mas, 2006), and by the Ebro Massif, an area with very little subsidence. However, borehole (Fig. 15A) and seismic data show that in this area some scattered tectonic depressions contain Lower Cretaceous sediments (Mas et al., 2002a; 2004), which indicates that rifting activity was not totally absent in the area between both basins. Given these paleogeographic context, and the fact that the NW outcrops of the Leza Fm are very close to abundant early Aptian marine deposits of the Basque-Cantabrian Basin, (Fig. 15A), we propose that, in addition to the clear Iberian affinity of the Cameros Basin, influence of the Basque-Cantabrian marine realm should also be considered for the early Aptian, since the small subsident depressions of the Ebro Massif between both basins might have acted as seaways connecting the Basque-Cantabrian Basin with the Cameros Basin during moments of especially high sea-level, such as the early Aptian (Fig. 15B). This double marine affinity from the northwestern Boreal marine realm and the southwestern Tethyan marine realm is supported by paleontological data, such as the probable presence of Salpingoporella urladanasi in the Basque-Cantabrian Basin (Dragastan, 1982; Pascal, 1984) and in the Iberian Basin (Canerot et al., 1982), and the similarity of shark populations found in the early Aptian of the Cameros Basin with those found in the basins of the Boreal and the Tethyan realms (Bermúdez-Rochas, 2009; 2012).

During late Barremian-early Aptian times sedimentation in the northern and eastern margins of the Iberian plate was eminently marine, with reefal carbonate platforms ("Urgonian" platforms) being the most characteristic feature of this period in the Basque-Cantabrian, Pyrenean and Iberian basins. The early Aptian transgressive pulse is marked in these basins by a drowning of the carbonate platforms and the onset of facies of deeper environments, such as dark, ammonite-rich marls (see Berástegui et al., 2002; Mas et al., 2002b; 2004; Rosales et al., 2002; García-Mondéjar et al., 2004; Robador and García-Senz, 2004; and references in them). This fact indicates that the early Aptian transgression produced a landwards displacement of the facies belts, allowing that inland areas characterized by broad fluvio-lacustrine plains, such as the Cameros Basin (Enciso Gr), could be locally invaded by seawater, developing coastal-wetlands (Leza Fm). Facies similar to those of the Leza Fm, with coexistence of charophytes and poorly diverse dasycladales and foraminifers (including the two genera found in the Leza Fm, Salpingoporella and Istriloculina) have also been described in the upper Barremian of the Pyrenean Basin (Bernaus et al., 2003) and the Iberian Basin (Albrich et al., 2006; Climent-Domènech et al., 2009), supporting the idea of a landwards migration of facies due to the early Aptian transgression.

The Pyrenean and Iberian basins are separated by the Tertiary Ebro Basin, which is an area interpreted to be a paleogeographic high (the Ebro Massif) during Early Cretaceous times (e.g. Martín-Chivelet, et al., 2002 and references therein). However, three boreholes show Lower Cretaceous rocks below the Tertiary Ebro Basin (Fig. $15 \mathrm{~A}$ ), suggesting that, at least small areas of the Ebro Massif were subsident during periods of the Early Cretaceous. Since emerged areas of the Lower Cretaceous of NE Iberia are believed to have had a low topography, easily flooded during moments of high sea-level (Martín-Chivelet et al., 2002), these small depressions might point to an additional seaway that eventually connected areas of the Pyrenean and the Iberian Basin. This promising hypothesis deserves further research.

Although the Cameros Basin is tectonically related to the Iberian Basin, various facts suggest that a paleogeographic connection with the Basque-Cantabrian Basin, at least ephemeral or instable, should not be discarded for the transgressive peak of the middle-upper part of the early Aptian (Fig. 15B). Therefore, here we propose that during that period the northern margin of the Cameros Basin was configured as a coastal rift basin gulf (sensu Gawthorpe and Leeder, 2000) because sedimentation in it was controlled by rifting fractures but also by rising sea- 
level. This area had a probable paleogeography similar to a narrow seaway partially connecting the Tethys realm (Iberian Basin) to the Boreal realm (Basque-Cantabrian Basin) during the early Aptian (Fig. 15B), as it did during other periods of very high sea-level, such as the Aalenian (García-Frank et al., 2008), the Kimmeridgian (Benito et al., 2005), or the Cenomanian-Turonian (Alonso et al., 1993; Segura et al., 2004).

\section{Conclusions}

The Leza Fm is a carbonate unit from the northern Cameros Basin. This unit was deposited in a series of fault-bounded tectonic depressions distributed along the northern margin of the basin. The Leza Fm changes laterally to the underlying Jubera Fm, mainly composed by conglomerates formed in alluvial fans. The thickness of both units is also controlled by faults. These facts point to tectonics as the main factor generating accommodation space for both units. To the South, towards the centre of the Cameros Basin, the Leza Fm changes laterally to mixed carbonate-siliciclastic deposits of the Enciso Gr deposited in fluvio-lacustrine environments.

Detailed sedimentological analysis shows that the Leza Fm had significant marine influence during its sedimentation, especially in the middle and upper part of the unit. This is indicated by sedimentary structures of tidal origin, and very common marine microfossils, such as dasycladales (Salpingoporella urladanasi) and miliolid foraminifers (cf. Istriloculina), as well as homogeneous populations of porocharacean charophytes, which indicate brackish conditions. Thus, the Leza Fm is interpreted as deposited in a carbonate system of coastal-wetlands, with variable influence of alluvial clastic deposits.

New biostratigraphic and sedimentological data confirm that the Leza Fm, the Jubera Fm and the Enciso Gr belong to the same depositional sequence, upper Barremian - lower Aptian in age. This dating is further refined by comparison of the sedimentological evolution of the Leza Fm with the eustatic evolution of neighbouring marine basins. A transgressive trend is observed in all the lithosomes of the Leza Fm, towards the upper part of the unit. Therefore, the upper part of the Leza Fm can be correlated with the highest sea-level peak of the late Barremian-early Aptian period, which is widely observed in the middle-upper part of the early Aptian. When this early Aptian transgression reached the northern margin of the Cameros Basin, eustatic accommodation space was generated, in addition to the accomodation space created by tectonics.

An extensive compilation of paleogeographic data shows that this early Aptian transgression probably reached the northern Cameros Basin both from the Ibe- rian Basin to the $\mathrm{SE}$ and from the Basque-Cantabrian Basin on the NW. The early Aptian paleogeography of NE Iberian plate was therefore dominated by low and flat areas with some subsiding zones that allowed the transgression to reach the Cameros Basin, located in a central part of the plate. During this period the northern Cameros Basin was similar to a coastal rift basin gulf that probably linked the Boreal and the Tethyan realms.

\section{Acknowledgements}

This study was funded by the Spanish DIGICYT Project CGL2011-22709, by the research group "Sedimentary Basin Analysis" UCM-CM 910429 of the Complutense University of Madrid and by a FPU scholarship of the Spanish Department of Education. Esmeralda Caus, Marc Conrad, Nicolaos Carras and Ioan Bucur provided paleontological classifications and advices that have been extremely useful for our study. We thank Beatriz Moral, Gilberto Herrero and Juan Carlos Salamanca for preparing the thin sections; Modesto Escudero for his constant help with the computer, the printer and the scanner; Laura Donadeo for providing many of the references used; and Valle López for support with ArcGIS. The manuscript was improved by comments of reviewers Gilbert Camoin and Carles Martín-Closas, who was also very helpful with the study of charophytes. We are also grateful to José López-Gómez and Javier Martín-Chivelet for their support during the editorial process. We thank Andrea Baza for helping to stain the thin sections, Silvia Omodeo for field-work support, and Belén Galán for field-work support and crucial help with the figures and references of the manuscript.

\section{References}

Albrich, S., Bernaus, J. M., Boix, C., Caus., E., Martín-Closas, C., Salas, R., Vicedo, V., Villalonga, R. (2006): Caracterización bioestratigráfica y paleoambiental del Cretácico Inferior (Berriasiense-Barremiense) Del Macizo De Garraf (Cadena Costera Catalana). Revista Española de Micropaleontología 38(2-3), 429-452.

Alonso, A., Mas, J. R. (1993): Control tectónico e influencia del eustatismo en la sedimentación del Cretácico inferior de la cuenca de Los Cameros. Cuadernos de Geología Ibérica 17, 285-310.

Alonso, A., Mas, J. R. (1988): La transgresion Aptiense al sur del Moncayo (límite de las provincias de Soria y Zaragoza). II Congreso geológico de España Vol 1, Granada: p. 11-15.

Alonso, A., Mas, J. R, Meléndez, N. (1986-1987): Los arrecifes coralinos del Malm en la Sierra de los Cameros (La Rioja, España). Acta Geológica Hispánica 21-22, 293-306.

Alonso, A., Floquet, M., Mas, R., Meléndez, A. (1993): Late Cretaceous Platforms: Origin and evolution, Iberian Range, Spain. In: J. A. Toni Simo, R. W. Scott, J. P. Masse (eds.), Cretaceous Carbonate Platforms, AAPG Memoir 56: 297-313.

Alonso-Azcárate, J. (1997): Evolución de los filosilicatos y génesis de los yacimientos de pirita en la cuenca de Cameros: su relación con las facies sedimentarias y el metamorfismo. PhD Thesis. Universidad 
Complutense de Madrid, $544 \mathrm{p}$.

Alonso-Azcárate, J., Rodas, M., Barrenechea, J. F., Mas, J. R. (1999): Factores que controlan la evolución de los parámetros cristaoquímicos y asociaciones minerales en las rocas sedimentarias del Grupo Enciso (Cretácico Inferior) Cuenca de Cameros, La Rioja (Norte de España). Revista de la Sociedad Geológica de España 12: 439-451.

Alonso-Zarza, A. M., Wright, V. P. (2010): Chapter 2: Palustrine carbonates. In: A. M. Alonso-Zarza, L. H. Tanner (eds.), Carbonates in continental settings: geochemistry, diagenesis and applications, Elsevier, Amsterdam: 319 p. doi:10.1016/S0070-4571(09)06102-0

Arnaud-Vanneau, A. (1980): Micropaléontologie, paléoécologie et sédimentologie d'une plate-forme carbonatée de la marge passive de la Téthys : l'Urgonien du Vercors septentrional et de la Chartreuse (Alpes occidentales). Géologie Alpine, Mémoire 10, 874 p.

Arnaud-Vanneau, A., Arnaud, H. (1990): Hauterivian to Lower Aptian carbonate shelf sedimentation and sequence stratigraphy in the Jura and northern Subalpine chains (southeastern France and Swiss Jura). Spec. Pubis int. Ass. Sediment 9, 203-233. doi:10.1002/9781444303834.ch8

Arribas, M. E., Mas, J. R., Arribas, J., Benito, M. I., Le Pera, E. (2009): Marine influence at the last rifting stages of a continental basin. The northermost Cameros basin record (Early Cretaceous, north Spain). 27 IAS Meeting of Sedimentoloy, Alghero: p. 434.

Bachmann, M., Hirsch, F. (2006): Lower Cretaceous carbonate platform of the eastern Levant (Galilee and the Golan Heights): stratigraphy and second-order sea-level change. Cretaceous Research 27, 487512. doi:10.1016/j.cretres.2005.09.003

Benito, M. I., Mas, R. (2006): Sedimentary evolution of the Torrecilla Reef Complex in response to tectonically forced regression (Early Kimmeridgian, Northern Spain). Sedimentary Geology 183, 31-49. doi:10.1016/j.sedgeo.2005.09.007

Benito, M. I., Kyger, C. L., Mas, R. (2005): Late Jurassic paleogeography and paleoclimate in the Northern Iberian Basin of Spain: constraints from diagenetic records in reefal and continental carbonates. Journal of Sedimentary Research 75, 82-96. doi: 10.2110/jsr.2005.008

Berástegui, X., Caus, E., Puig, C. (2002): Chapter 12 Cretaceous: Pyrenees. In: W. Gibbons, M. T. Montero (eds.), The Geology of Spain. Geological Society, London: 265-272.

Bermúdez-Rochas, D. D. (2009): Early Cretaceous sharks from the Cameros Basin (North of Spain). 8 International Symposium on the Cretaceous System, Plymouth: p. 161.

Bermúdez-Rochas, D. D. (2012): An overview of the hybodont record of the Cameros Basin (northwest of Iberian Range, Spain). 60th Annual symposium of vertebrate palaeontology and comparative anatomy. 21st Symposium of palaentological preparation and conservation, Oxford: p. 7.

Bernaus, J. M., Arnaud-Venneau, A., Caus, E. (2002): Stratigraphic distribution of Valanginian-Early Aptian shallow-water benthic foraminifera and algae, and depositional sequences of a carbonate platform in a tectonically-controlled basin: the Organyà Basin, Pyrenees, Spain. Cretaceous Research, 23, 25-36. doi:10.1006/cres.2001.0300

Bernaus, J. M., Arnaud-Vanneau, A., Caus, E. (2003): Carbonate platform sequence stratigraphy in a rapidly subsiding area: the Late Barremian-Early Aptian of the Organyà basin, Spanish Pyrenees. Sedimentary Geology 159, 177-201. doi:10.1016/S0037-0738(02)00316-0

Black, M. (1933): The algal sedimentation of Andros Island Bahamas. Phil. Trans. Roy. Soc. London, Series B: Biological Sciences 222, 789-803.

Bosence, D. W. J. (1998): Chapter A2: Stratigraphic and sedimentological models of rift basins. In: B. H. Purser, D. W. J. Bosence (eds.), Sedimentation and Tectonics in Rift Basins. Red Sea and Gulf of Aden. Chapman and Hall, London: 9-25. doi:10.1007/978-94-011-4930-3 2

Bover-Arnal, T., Moreno-Bedmar, J. A, Salas, R., Skelton, P. W., Bitzer, K., Gili, E. (2010): Sedimentary evolution of an Aptian syn-rift carbonate system (Maestrat Basin, E Spain): effects of accommo- dation and environmental change. Geologica Acta 8 (3), 249-280. doi:10.1344/105.000001533

Brenchley, P.J., Harper, D.A.T. (1998): Palaeoecology: Ecosystems, environments and evolution. Chapman \& Hall, London: $402 \mathrm{p}$.

Brenner, P., Wiedmann, J. (1975): Nuevas aportaciones al conocimiento del «Weald» celtibérico septentrional y sus relaciones paleogeográficas. Actas $1^{\circ}$ Symposium sobre el Cretáceo de la Cordillera Ibérica, Cuenca: p. 125-134.

Canerot, J., Cugny, P., Pardo, G., Salas, R., Villena, J. (1982): Capítulo 6: Ibérica Central-Maestrazgo. In: El cretácico de España. Universidad Complutense de Madrid-Instituto de Geología Económica CSIC, Madrid: 273-344.

Carras, N., Conrad, M. A., Radoicic, R., (2006): Salpingoporella, a common genus of Mesozoic Dasycladales (calcareous green algae). Revue de Paléobiologie, Genève 25 (2), 457-517.

Casanovas, M. L., Ezquerra, R., Fernández, A., Pérez-Lorente, F., Santafé, J. V., (1990): Huellas de dinosaurio en Soto de Cameros (La Rioja, España). Zubía 8, 49-71.

Casanovas, M. L., Ezquerra, R., Pérez-Lorente, F., Santafé, J. V., Torcida, F. (1992): Un grupo de saurópoodos del yacimiento Soto 2. La Rioja (España). Zubia 10, 45-52.

Casas-Sainz, A. M., Simón-Gómez, J. L. (1992): Stress field and thrust kinematics: a model for the tectonic inversion of the Cameros Massif (Spain). Journal of Structural Geology 14 (5), 521-530.

Casas-Sainz, A.M., Gil-Imanz, A. (1994): Discusión a Mas et al. (1993) - Evolución tectonosedimentaria de una cuenca extensional intraplaca: la cuenca finijurásica-eocretácica de Los Cameros (La RiojaSoria). Revista de la Sociedad Geológica de España 7 (3-4), 337-345.

Casas, A. M., Villalaín, J. J., Soto, R., Gil-Imaz, A., del Río, P., Fernández, G. (2009): Multidisciplinary approach to an extensional syncline model for the Mesozoic Cameros Basin (N Spain). Tectonophysics 470, 3-20. doi:10.1016/j.tecto.2008.04.020

Clemente, P. (2010): Review of the Upper Jurassic-Lower Cretaceous Stratigraphy in Western Cameros basin, Northern Spain. Revista de la Sociedad Geológica de España 23 (3-4), 101-143.

Climent-Domenech, H., Martín-Closas, C., Salas, R. (2009): Charophyte-rich microfacies in the Barremian of the Eastern Iberian Chain (Spain). Facies 55, 387-400. doi:10.1007/s10347-008-0173-1

Collier, R.E.L. (1990): Eustatic and tectonic controls upon Quaternary coastal sedimentation in the Corinth basin, Greece. Journal of the Geological society of London 147, 301-314. doi:10.1144/ gsjgs.147.2.0301

Conrad, M. A., Peybernès, B., Radoicic, R. (1977): Salpigoporella urladanasi, n. sp., une Dasycladale du Cretacé inferieur dÉsagne et de Yougoslavie. Géologie Mediterranéenne 4 (2), 73-82.

Cross, N. E., Purser, B. H., Bosence, D. W. J. (1998): Chapter D6: The tectono-sedimentary evolution of a rift margin carbonate platform: Abu Shaar, Gulf of Suez, Egypt. In: B. H. Purser, D. W. J. Bosence (eds.), Sedimentation and Tectonics in Rift Basins. Red Sea and Gulf of Aden. Chapman and Hall, London: 272-295. doi:10.1007/978-94011-4930-3 16

De Benedictis, D., Bosence, D., Waltham, D. (2007): Tectonic control on peritidal carbonate parasequence formation: an investigation using forward tectono-stratigraphic modelling. Sedimentology 54, 587-605. doi:10.1111/j.1365-3091.2006.00851.x

Demicco, R.V. (1983): Wavy and lenticular-bedded carbonate ribbon rocks of the Upper Cambrian Conococheague Limestone, Central Appalachians. Journal of Sedimentary Research 53, 1121-1132.

Díaz Martínez, E. (1988): El Cretacico inferior del sector de Jubera (norte de la sierra de Los Cameros, La Rioja): relación entre tectónica y sedimentación. Comunicaciones vol 1, II Congreso Geológico de España, Granada: p. 67-70.

Dickson, J.A.D. (1966): Carbonate identification and genesis as revealed by staining. Journal of Sedimentary Petrology 36, 491-505. 
Doublet, S., García, J. P., Guiraud, M., Ménard, A. (2003) Wave-dominated siliciclastic and carbonate sedimentation in a Lower Cretaceous lake (Cameros basin, northern Spain). Journal of Iberian Geology 29, 11-30.

Doublet, S. (2004): Contrôles tectonique et climatique del'enregistrement stratigraphique dans un basin continental de rift: le basin de Cameros (Jurassique supérieur-Crétacé inferieur) provinces de Soria-La Rioja, Espagne. PhD Thesis. Université de Bourgogne. 465 p.

Dragastan, O. (1982): Lower Cretaceous marine algae and calpionellidae from Candas (San Pedro)-Asturias Province (Spain). Cuadernos de Geología Ibérica 3, 125-143.

Dunham, R.J. (1962): Classification of carbonate rocks according to depositional texture. In: classification of carbonate rocks. $A A P G$ Memoire 1, 108-121.

Freytet, P., Verrechia, E. P. (2002): Lacustrine ans palustrine carbonate petrography: an overview. Journal of Paleolimnology 27, 221-237.

García-Frank, A., Ureta, S., Mas, R. (2008): Aalenian pulses of tectonic activity in the Iberian Basin, Spain. Sedimentary Geology 209, 15-35. doi:10.1016/j.sedgeo.2008.06.004

García-Mondéjar, J. (1990): The Aptian-Albian carbonate episode of the Basque-Cantabrian Basin (northern Spain): general characteristic, controls and evolution. IAS Special PubIications 9, 257-290. doi: DOI:10.1002/9781444303834.ch10

García-Mondéjar, J., Fernández-Mendiola, P. A., Agurrezabala, L.M., Aranburu, A., López-horgue, M.A., Iriarte, E., Martínez de Rituerto, S. (2004): Aptiense-Albiense de la Cuenca Vasco-Cantábrica. In: J. A. Vera, Geología de España. Sociedad Geológica de España-Instituto Geológico y Minero, Madrid: 291-296.

García-Mondéjar, J., Owen, H.G., Raisossadat, N., Fernández-Mendiola, P.A. (2009) The Early Aptian of Aralar (northern Spain): stratigraphy, sedimentology, ammonite biozonation, and OAE1. Cretaceous Research 30, 434-464. doi:10.1016/j.cretres.2008.08.006

García-Senz, J. (2002): Cuencas extensivas del Cretácico inferior en los Pirineos centrales, formación y subsecuente inversión. $\mathrm{PhD}$ Thesis. Universitat de Barcelona. $310 \mathrm{p}$.

Gawthorpe, R.L., Leeder, M.R. (2000): Tectono-sedimentary evolution of active extensional basins. Basin Research 12, 195-218. doi: 10.1046/j.1365-2117.2000.00121.x

Gawthorpe, R.L., Sharp, I., Underhill, J.R., Gupta, S. (1997): Linked sequence stratigraphic and structural evolution of propagating normal faults. Geology 25, 795-798. doi:10.1130/00917613(1997)025<0795:LSSASE $>2.3$. CO;2

Gebelein, C.D. (1977): Dynamics of recent carbonate sedimentation and ecology. Cape Sable, Florida. Brill, Leiden: 120 p.

Ginsburg, R.N. (ed.) (1977): Tidal deposits: a casebook of recent examples and fossil counterparts. Springer-Verlag, Berlin: 428 p.

González Fernández, B., Menéndez Casares, E., Gutierrez Claverol, M., García-Ramos, J. C. (2004): Litoestratigrafía del sector occidental de la cuenca cretácica de Asturias. Trabajos de Geología, Universidad de Oviedo 24, 43-80.

Guimerà, J., Alonso, A., Mas, J. R. (1995): Inversion of an extensionalramp basin by a newly formed thrust: the Cameros basin (N Spain). In: J. G. Buchanan, P. G. Buchanan (eds.), Basin Inversion. Geological Society, London, Special Publications 88, 433-453.

Guiraud, M. (1983): Evolución tectono-sedimentaire du Bassin Wealdien (Cretace inferieur) en ralais de decrochemets de Logroño-Soria ( $N$-W Espange). PhD Thesis. Universite des Sciences et Techniques du Languedoc. $185 \mathrm{p}$.

Guiraud, M., Seguret, M. (1985): A releasing solitary overstep model for the late Jurassic-Early Cretáceous (Wealdian) Soria strike-slip basin (Northern Spain). The Society of Economic Paleontologist and Mineralogists. Special Publ. 37, 159-175.

Haq, B. U., Al-Qahtani, A. M. (2005): Phanerozoic cycles of sea-level change on the Arabian Platform. GeoArabia 10 (2), 127-159.

Hardie, L.A. (ed.) (1977): Sedimentation on the modern carbonate tidal flats of Northwest Andros Island, Bahamas. The John Hopkins University Press, Baltimore: 202 p.

Hay, W.W., De Conto, R.M., Wold, C.N., Wilson, K.M., Voigt, S., Schulz, M., Rossby-Wold, A., Dullo, W.-Chr., Ronov, A.B., Balukhovsky, A.N., Söding, E., (1999): An alternative global Cretaceous paleogeography. In: E. Barrera, C.C. Johnson, (eds.), Evolution of Cretaceous Ocean/Climate System. Geological Society of America Special Paper 332: 1-47.

Hernández Samaniego, A., Ramírez Merino, J. I., Olivé Davó, A., Álvaro López, M., Ramírez del Pozo, J., Aguilar, M. J., Meléndez Hevia, A. (1990): Hoja geológica num. 242 (Munilla). Mapa geológico de España 1:50.000, Segunda serie, I.G.M.E, Madrid.

Huang, C., Hinnov, L., Fischer, A. G., Grippo, A., Herbert, T. (2010): Astronomical tuning of the Aptian Stage from Italian reference sections. Geology 38 (10), 899-902. doi:10.1130/G31177.1

IGME (1987): Contribución de la exploración petrolifera al conocimiento de la geología de España. Instituto Geológico de España, Madrid: $465 \mathrm{p}$.

Ingersoll, R. V., Busby, C. J. (1995): Tectonics of Sedimentary Basins. In: C. J. Busby, R. V. Ingersoll (eds.), Tectonics of Sedimentary Basins, Blackwell Science, Malden: 1-51.

Iovcheva, P. M. (1962): Foraminifera of the oolitic limestone of the Aptian along the Rusenski Low River. Bulg. Geol. Soc. Rev. 23 (1), 41-61.

Jacquin, T., Rusciadelli, G., Amedro, F., De Graciansky, P-C., MagniezJannin, F. (1998): The North Atlantic cycle: an overview of 2nd-order transgressive/regressive facies cycles in the Lower Cretaceous of Western Europe. In: P-C. De Graciansky, J. Hardenbol, T. Jacquin, R. P. Vail (eds.), Mesozoic and Cenozoic Sequence Stratigrapy of European Basins. SEPM Special Publication 60, 397-409. doi:10.2110/ pec.98.02.0397

Kneuper-Haack, F. (1966): Ostracoden aus dem Wealden der Sierra de Cameros (Nordwestliche Iberiche Ketten). Beih. Geol. Jb. 44, 165209.

Lambeck, K., Cloetingh, S., McQueen, H. (1987): Intraplate stresses and apparent changes in sea level: the basins of northwestern Europe. In: C. Beaumont, A. J. Tankard (eds.), Sedimentary Basins and BasinForming Mechanisms. Memoir 12, Canadian Society of Petroleum Geologists, Canada: 259-268.

Lasemi, Y., Jahani, D., Amin-Rasouli, H., Lasemi, Z. (2012) Ancient carbonate tidalites. In: R.A. Davis, Jr., R.W. Dalrymple (eds.) Principles of tidal sedimentology. Springer, New York: 567-607. doi:10.1007/978-94-007-0123-6_21

Leeder, M.R., Gawthorpe, R.L. (1987): Sedimentary models for extensional tilt-block/half-graben basins. In: M.P. Coward, J.F. Dewey, P.L. Hancock (eds.) Continental extensional tectonics. Geological Society, London, Special Publications 28: 139-152. doi:10.1144/GSL. SP.1987.028.01.11

Leeder, M. R. (1995): Chapter 3: Continental Rifts and Proto-Oceanic Rift Troughs. In: C. J. Busby, R. V. Ingersoll (eds.), Tectonics of Sedimentary Basins, Blackwell Science, USA: 119-148.

Leeder, M. (2011): Sedimentology and Sedimentary Basins. From turbulence to Tectonics. Wiley-Blackwell, Oxford: 768 p.

Lezin, C., Bonnet, L., Rey, J., Caetano, P. S., Gonçalves, P., Rocha, F., Rocha, R., B. (2010): Orbital forcing of stratal patterns in an inner platform carbonate succession: an example from an Upper Hauterivian series of the Lusitanian Basin, Portugal. Ciências da Terra (UNL) $17,29-44$.

Loeblich, A. R. Jr., Tappan, H. (1988): Foraminiferal genera and their classifications. Van Noslrand Reinhold, New York: 970 p.

Martín-Chivelet, J. (Coord.), Berástegui, X., Rosales, I., Vilas, L., Vera, J. A., Caus, E., Gräfe, K-U., Mas, R., Puig, C., Segura, M., Robles, S., Floquet, M., Quesada, S., Ruiz-Ortiz, P., Fregenal-Martínez, M. A., Salas, R., Arias, C., García, A., Martín-Algarra, A., Meléndez, M. N., Chacón, B., Molina, J. M., Sanz, J. L., Castro, J. M., García-Hernán- 
dez, M., Carenas, B., García-Hidalgo, J., Gil, J., Ortega, F. (2002): Chapter 12: Cretaceous. In: W. Gibbons, M. T. Montero (eds.), The Geology of Spain. Geological Society, London: 255-292.

Martín-Closas, C., Grambast-Fessard, N. (1986): Les charophytes du Crétacéinférieur de la région du Maestrat (ChaîneIbérique, Catalanides, Espagne). Paléobiologie Continentale 15, 1-66.

Martín-Closas, C., Alonso, A. (1998) Estratigrafía y bioestratigrafía (Charophyta) del Cretácico Inferior en el sector occidental de la Cuenca de Cameros (Cordillera Ibérica). Revista de la Sociedad Geológica de España 11, 253-269.

Márton, E., Ćosović, V., Bucković, D., Moro, A. (2010): The tectonic development of the Northern Adriatic region constrained by Jurassic and Cretaceous paleomagnetic results. Tectonophysics 490, 93-102. doi:10.1016/j.tecto.2010.04.032

Mas, R. (1982): El Cretácico Inferior de la región noroccidental de la provincia de Valencia. Seminarios de Estratigrafía, Series Monografías 8. Universidad Complutense-Instituto de Geología Económica CSIC, Madrid: $408 \mathrm{p}$.

Mas, J.R., Alonso, A., Díaz, E. (1990): Tectonically controlled carbonate lacustrine systems in the northern margin of the Cameros Basin (Lower Cretaceous, north Spain). Volumen de comunicaciones 6, Meeting of the European Geological Societies, Lisboa: p. 55.

Mas, J.R., Alonso, A., Guimera, J. (1993): Evolución tectonosedimentaria de una cuenca extensional intraplaca: La cuenca finijurásicaeocretácica de Los Cameros (La Rioja-Soria). Rev. Soc. Geol. España 6 (3-4), 129-144.

Mas, R., Benito, M. I., Arribas, J., Serrano, A., Guimerà, J., Alonso, A., Alonso-Azcárate, J. (2002a): La cuenca de Cameros: desde la extensión finijurásica-eocretácica a la inversión terciaria - implicaciones en la exploración de hidrocarburos. Zubia Monográfico 14, 9-64.

Mas, R., Segura, M., Salas, R., Fregenal-Martínez, M. A., Sanz, J. L., García, A., Meléndez, M. N., Carenas, B., García-Hidalgo, J., Ortega, F., Gil, J., Martín-Chivelet, J. (2002b): Chapter 12 Cretaceous: The Iberian basin. In: W. Gibbons, M. T. Montero (eds.), The Geology of Spain. Geological Society, London: 284-288.

Mas, R., García, A. (Coord.), Mas, R., García, A., Salas, R., Meléndez, A., Alonso, A., Aurel, M., Bádenas, B., Benito, M. I., Carenas, B., García-Hidalgo, J. F., Gil, J., Segura, M. (2004): Segunda Fase de rifting: Jurásico Superior-Cretácico Inferior. In: J. A. Vera, Geología de España. Sociedad Geológica de España-Instituto Geológico y Minero, Madrid: 503-510.

Mas, J. R., Benito, M. I., Arribas, J., Alonso, A., Arribas, M.E., Lohomann, K. C., Hernán, J., Quijada, E., Suárez, P., Omodeo, S. (2011): Evolution of an intra-plate rift basin: the Latest Jurassic-Early Cretaceous Cameros Basin (Northwest Iberian Ranges, North Spain) Geo-Guías 8, 117-154.

Masse, J.P., Bouaziz, S., Amon, E.O., Baraboshkin, E., Tarkowski, R., Bergerat, F., Sandulescu, M., Platel, J.Pl, Canerot, J., Guiraud, R., Poisson, A., Ziegler, M., Rimmele, G. (2000): Map 13 - Early Aptian (112-114 Ma). In: J. Dercourt, M., Gaetani, B., Vrielynck, E. Barrier, B. Biju-Duval, M.F., Brunet, J.P. Cadet, S. Crasquin, M. Sandulescu (eds.), Atlas Peri-Tethys, Palaeogeographical maps. CCGM/CGMW, Paris.

Masse, J. P., Fenerci, M., Pernarcic, E. (2003): Palaeobathymetric reconstruction of peritidal carbonates Late Barremian, Urgonian, sequences of Provence (SE France). Palaeogeography, Palaeoclimatology, Palaeoecology 200, 65-81. doi:10.1016/S0031-0182(03)00445-0

Masse, J-P., Tüysüz, O., Fenerci-Masse, M., Özer, S., Sari, B., (2009): Stratigraphic organisation, spatial distribution, palaeoenvironmental reconstruction, and demise of Lower Cretaceous (Barremian-lower Aptian) carbonate platforms of the Western Pontides (Black Sea region, Turkey). Cretaceours Research 30, 1170-1180. doi:10.1016/j. cretres.2009.05.004

Masse, J-P., Fenerci-Masse, M. (2011): Drowning discontinuities and stratigraphic correlation in platform carbonates. The late Barremianearly Aptian record of southeast France. Cretaceous Research 32, 659-684. doi:10.1016/j.cretres.2011.04.003

Meléndez, M.N (1983): El Cretácico de la región de Cañete - Rincón de Ademuz (provincias de Cuenca y Valencia). Seminarios de Estratigrafía, Series Monografías 9. Universidad Complutense-Instituto de Geología Económica CSIC, Madrid: 242 p.

Miall, A.D., Miall, C.E. (2001): Sequence stratigraphy as a scientific enterprise: the evolution and persistence of conflicting paradigms. EarthScience Reviews 54, 321-348. doi:10.1016/S0012-8252(00)00041-6

Mojon, P.O. (1989): Polymorphisme écophénotypique et paléoécologique des Porocharacées (Charophytes) du Crétacé basal (Berriasien) du Jura Franco-Suisse. Revue de Paléobiologie 2, 505-524

Moratalla, J.J., Sanz, J.L. (1997): Cameros Basin Megatracksite. In: P.J. Currie, K. Padian (eds.), Encyclopedia of Dinosaurs, Academic Press, New York: 87-90.

Moratalla, J.J., Hernán, J. (2010): Probable palaeogeographic influences of the Lower Cretaceous Iberian rifting phase in the Eastern Cameros Basin (Spain) on dinosaur trackway orientations. Palaeogeography, Palaeoclimatology, Palaeoecology 295, 116-130. doi:10.1016/j.palaeo.2010.05.027

Moreno-Bedmar, J. A., Company, M., Bover-Arnal, T., Salas, R., Delanoy, G., Martínez, R., Grauges, A. (2009): Biostratigraphic characterization by means of ammonoids of the lower Aptian Oceanic Anoxic Event (OAE 1a) in the eastern Iberian Chain (Maestrat Basin, eastern Spain). Cretaceous Research 30, 864-872. doi:10.1016/j.cretres.2009.02.004

Muñoz, A., Soria, A., Canudo, J. I., Casas, A. M., Gil, A., Mata, M. P. (1997): Caracterización estratigráfica y sedimentológica del Albiense marino del borde Norte de la Sierra de Cameros. Implicaciones Paleogeográficas. Cuadernos de Geología Ibérica 22, 139-163.

Mutterlose, J. (1998): The Barremian-Aptian turnover of biota in northwestern Europe: evidence from belemnites. Palaeogeography, Palaeoclimatology, Palaeoecology 144, 161-173. doi:10.1016/S00310182(98)00081-9

Najarro, M., Rosales, I., Moreno-Bedmar, J. A., De Gea, G. A, Barrón, E., Company, M., Delanoy, G. (2011): High-resolution chemo- and biostratigraphic records of the Early Aptian oceanic anoxic event in Cantabria (N Spain): Palaeoceanographic and palaeoclimatic implications. Palaeogeography, Palaeoclimatology, Palaeoecology 299, 137-158. doi:10.1016/j.palaeo.2010.10.042

Neagu, T. (1984): Nouvelles donnees sur la morphologie du test, sur la systematique et la nomenclature des miliolides agatisthegues du Mesozoique. Revista Española de Micropaleontología 16, 75-90.

Ochoa, M. (2006): Procedencia y diagénesis del registro arenoso del Grupo Urbión (Cretácico inferior) de la Cuenca de Cameros (Cordillera Ibérica septentrional). $\mathrm{PhD}$ Thesis. Universidad Complutense de Madrid, $240 \mathrm{p}$.

Ogg, J.G., Hinnov, L.A. (2012): Cretaceous. In: F.M. Gradstein, J.G. Ogg, M.D. Schmitz, G.M. Ogg (eds.), The Geologic Time Scale 2012 Volume 2. Elsevier, Oxford: 793-853. doi:10.1016/B978-0-44459425-9.00027-5

Pascal, A. (1984): Les systemes biosedimentaries urgoniens (Aptien-Albien) sur la marge Nord-Iberique. PhD Thesis. Universite de Dijon: $561 \mathrm{p}$.

Pérez-Lorente, F. (2002): La distribución de yacimientos y de tipos de huellas de dinosaurio en la cuenca de Cameros (La Rioja, Burgos, Soria. España) Zubía monográfico 14, 191-210.

Peropadre, C. (2012): El Aptiense del margen occidental de la cuenca del Maestrazgo: controles tectónico, eustático y climático en la sedimentación. PhD Thesis. Universidad Complutense de Madrid.

Perrin, C., Plaziat, J-C., Rosen, B. R. (1998): Chapter D7: Miocene coral reefs and reef corals of the south-western Gulf of Suez and northwestern Red sea: distribution, diversity and regional environmental 
controls. In: B. H. Purser, D. W. J. Bosence (eds.), Sedimentation and Tectonics in Rift Basins. Red Sea and Gulf of Aden. Chapman and Hall, London: 296-319. doi:10.1007/978-94-011-4930-3 17

Peybernès, B. (1976): Le Jurassique et le Cretace Inferieur des Pyrenees Franco-Espagnoles entre la Garonne et la Mediterranee. PhD Thesis. Université Paul-Sabatier, 453 p.

Pietman, W.C. (1978): Relationship between eustacy and stratigraphic sequences of passive margins. Geological Society of America bulletin 89, 1389-1403. doi:10.1130/0016-7606(1978)89<1389:RBEASS $>2$. $0 . \mathrm{CO} ; 2$

Platt, N.H., Wright, V.P. (1992): Palustrine carbonates and the Florida Everglades: towards and exposure index for the fresh-water environment? Journal of Sedimentary Petrology 62, 1058-1071.

Plaziat, J-C., Montenat, C., Barrier, P., Janin, M-C., Orszag-Sperber, F., Philobbos, E. (1998): Chapter D3: Stratigraphy of the Egyptian syn-rift deposits: correlations between axial and peripheral sequences of the north-western Red Sea and Gulf of Suez and their relations with tectonic and eustacy. In: B. H. Purser, D. W. J. Bosence (eds.), Sedimentation and Tectonics in Rift Basins. Red Sea and Gulf of Aden. Chapman and Hall, London: 211-222. doi:10.1007/978-94-011-49303_13

Quijada, I.E., Suarez-Gonzalez, P., Benito, M.I., Mas, J.R., Alonso, A. (2010): Un ejemplo de llanura fluvio-deltaica influenciada por las mareas: el yacimiento de icnitas de Serrantes (Grupo Oncala, Berriasiense, Cuenca de Cameros, N. de España). Geogaceta 49, 15-18.

Quijada, I.E., Suarez-Gonzalez, P., Benito, M.I., Mas, J.R. (2013): Depositional depth of laminated carbonate deposits: insights from the lower cretaceous valdeprado formation (Cameros Basin, N Spain). Journal of Sedimentary Research 83, 241-257. doi:10.2110/jsr.2013.23

Quijada, I.E., Suarez-Gonzalez, P., Benito, M.I., Mas, R. (2014): Tidal versus continental sandy-muddy flat deposits: evidence from the Oncala Group (Early Cretaceous, N Spain). In: B. Tessier, J.Y. Reynaud (eds.). International Association of Sedimentologists Special Publication 48 , in press.

Quijada, I.E., Suarez-Gonzalez, P., Benito, M.I., Mas, J.R. (2013): New insights on the stratigraphy and sedimentology of the Oncala Group (eastern Cameros Basin): implications for the paleogeographic reconstruction of NE Iberia at Berriasian times. Journal of Iberian Geology 39, 313-334. doi:10.5209/rev JIGE.2013.v39.n2.42503

Ravnas, R., Steel, R.J. (1998): Architecture of marine rift-basin successions. American Association of Petroleum Geologist Bulletin 82, 110-146.

Reed, D.J. (2002): Understanding Tidal Marsh Sedimentation in the Sacramento-San Joaquin Delta, California. Journal of Coastal Research, Special Issue 36, 605-611.

Rey, J., Bilotte, M., Peybernès, B. (1977): Analyse biostratigraphique et paléontologique de l'Albien marin d'Estremadura (Portugal). Geobios 10(3), 369-393.

Robador, A., García-Senz, J. (2004): El Cretácico Inferior de la vertiente surpirenaica. In: J. A. Vera, Geología de España. Sociedad Geológica de España-Instituto Geológico y Minero, Madrid:285-291.

Rodríguez Quiroga, A. (2011): Significado de las facies urgonianas al $N$ del cabalgamiento de Cameros en el sector de Grávalos (N Cordillera Ibérica, La Rioja). Master Thesis. Universidad Complutense de Madrid. 57 p.

Rosales, I., Gräfe, K-U., Robles, S., Quesada, S., Floquet, M. (2002): Chapter 12 Cretaceous: The Basque-Cantabrian Basin. In: W. Gibbons, M. T. Montero (eds.), The Geology of Spain. Geological Society, London:272-281.

Rosell, J., Llompart, C. (1982): Capítulo 4: Pirineo. In: El cretácico de España. Universidad Complutense de Madrid-Instituto de Geología Económica CSIC, Madrid: 161-196.

Ruffell, A. (1991): Sea-level events during the Early Cretaceous in Western Europe. Cretaceous Research 12, 527-551.
Sacristán-Horjacada, S., Carrasco, A., Mas, R., Arribas, M.E. (2012): Comparación del registro estratigráfico de dos cubetas satélites asociadas a un sistema de rift: los surcos de Bijuesca y Bigornia (SE de la Cuenca de Cameros). Geo-Temas 13, $88+\mathrm{CD}$.

Sahagian, D., Pinous, O., Olferiev, A., Zakharov, V. (1996): Eustatic Curve for the Middle Jurassic-Cretaceous Based on Russian Platform and Siberian Stratigraphy: Zonal Resolution. American Association of Petroleum Geologist Bulletin 80 (9), 1433-1458.

Salas, R. (1987): El Malm i el Cretaci Inferior entre el Massís de Garrafi la Serra d'Espada. Anàlisi de conca. PhD Thesis, Universitat de Barcelona: $345 \mathrm{p}$.

Salas, R., Martín-Closas, C. (eds.) (1995): El Cretácico inferior del nordeste de Iberia. Publicacions de la Universitat de Barcelona: 153 p.

Salas, R., Guimerá, J., Mas, R., Martín-Closas, C., Meléndez, A., Alonso, A. (2001): Evolution of the Mesozoic Central Iberian Rift System and its Cainozoic inversion (Iberian chain). In: P.A. Ziegler, W. Cavazza, A.H.F. Robertson, S.Crasquin-Soleau (eds.), Peri-Tethys Memoir 6: Peri-Tethyanrift/wrench basins and passive margins. Mémoires du Musée national des Histoires naturelles de Paris 186, 145-185.

Salomon, J. (1982): Les formations continentals du JurassiqueSupérieur - Cretacé Inférieur (Espagne du Nord - ChaînesCantabrique et NW Ibérique). Mémoires géologiques de l'Université de Dijon 6: 228 p.

Schudack, M. (1987): Charophyten flora und fazielle Entwicklung der Grenzschichten mariner Jura / Wealden in den Nordwestlichen Iberischen Ketten (mit Vergleichen zu Asturien und Kantabrien). Palaeontographica Abteilung B 204, 1-180.

Schudack, M.E. (1993): Die Charophyten im Oberjura und Unterkreide West europas: mit einer phylogenetischen Analyse der Gesamt gruppe. Berliner Geowissenschaftliche Abhandlungen A 8, 1-209.

Schudack, U., Schudack, M. (2009): Ostracod biostratigraphy in the Lower Cretaceous of the Iberian chain (Eastern Spain). Journal of Iberian Geology 35, 141-168.

Segura, M., García-Hidalgo, J.F., Carenas, B., Gil, J., García, A. (2004): Evolución paleogeográfica de la Cuenca Ibérica en el Cretácico Superior. Geogaceta 36, 103-106.

Soria, A. R., Vennin, E., Meléndez, A. (1992): Estratigrafía y control tectónico en la evolución de las rampas carbonatadas del Cretácico inferior de la Cubeta de Oliete (Provincia de Teruel). Revista de la Sociedad Geológica de España 7 (1-2), 1994.

Stein, M., Föllmi, K. B., Westermann, S., Godet, A., Adatte, T., Matera, V., Fleitmann, D., Berner, Z. (2011): Progressive palaeoenvironmental change during the Late Barremian-Early Aptian as prelude to Oceanic Anoxic Event 1a: Evidence from the Gorgo a Cerbara section (Umbria-Marche basin, central Italy). Palaeogeography, Palaeoclimatology, Palaeoecology 302, 396-406. doi:10.1016/j.palaeo.2011.01.025

Suarez-Gonzalez, P., Quijada, I. E., Mas, J. R., Benito, M. I. (2010): Nuevas aportaciones sobre la influencia marina y la edad de los carbonatos de la Fm Leza en el sector de Préjano (SE de La Rioja). Cretácico Inferior, Cuenca de Cameros Geogaceta 49, 7-10.

Suarez-Gonzalez, P., Quijada, I. E., Benito, M. I., Mas, J. R., OmoedoSalé, S. (2011): Textbook example of tectonically controlled carbonate sedimentation at the active margin of a rift basin: the Leza Fm (Early Cretaceous, Cameros Basin, Spain). 28 IAS Meeting of Sedimentology, Zaragoza: p. 455.

Suarez-Gonzalez, P., Martín-Closas, P., Quijada, I. E., Benito, M. I., Mas, J. R. (2012): Calcareous algae (dasycladales and charophytes), essential for the sedimentological interpretation of ancient coastallakes systems. The Barremian-Aptian Leza Fm., Cameros Basin, N Spain. 29 IAS Meeting of Sedimentology, Schladming: p. 567.

Suarez-Gonzalez, P., Quijada, I.E., Benito, M.I., Mas, R. (2014): Do stromatolites need tides to trap ooids? Insights from a Cretaceous system of coastal-wetlands. In: B. Tessier, J.Y. Reynaud (eds.). International Association of Sedimentologists Special Publication 48, in press. 
Tischer, G. (1966): Über die Wealden-Ablagerung und die tektonik der östlichen Sierra de los Cameros in den nordwestlichen Iberischen Ketten (Spanien). Beihefte zum Geologischen Jahrbuch 44, 123-164.

Tyson, R. V., Funnell, B. M. (1987): European Cretaceous shorelines, stage by stage. Palaeogeography, Palaeoclimatology, Palaeoecology $59,69-91$.

Vilas, L., Alonso, A., Arias, c., García, A., Mas, J. R., Rincón, R., Meléndez, N. (1983): The Cretaceous of the Southwestern Iberian Ranges (Spain). Zitteliana 10, 245-254.
Waterkeyn A, Grillas P, Vanschoenwinkel B, Brendonck L. (2008): Invertebrate community patterns in Mediterranean temporary wetlands along hydroperiod and salinity gradients. Freshwater Biology 53, 1808-1822. doi:10.1111/j.1365-2427.2008.02005.x

Wilmsen, M. (2005): Stratigraphy and biofacies of the Lower Aptian of Cuchía (Cantabria, northern Spain). Journal of Iberian Geology 31(2), 253-275.

Ziegler, P.A. (1988): Evolution of the Arctic-North Atlantic and the Western Tethys. AAPG Memoir 43.

\section{APPENDIX}

Sheets of the Geological Map of Spain (MAGNA series) used for the compilation of paleogeographic data of the early Aptian.

\author{
013 - Avilés \\ 014 - Gijón \\ 015 - Lastres \\ 028 - Grado \\ 029 - Oviedo \\ 030 - Villaviciosa \\ 031 - Ribadesella \\ 032 - Llanes \\ 033 - Comillas \\ 034 - Torrelavega \\ 035 - Santander \\ 036 - Castro Urdiales \\ 037 - Algorta \\ 038 - Bermeo \\ 039 - Lequeitio \\ 052 - Proaza \\ 053 - Mieres \\ 056 - Carreña-Cabrales \\ 057 - Cabezon de la Sal \\ 058 - Los Corrales de Buelna \\ 059 - Villacarriedo \\ 060 - Valmaseda \\ 061 - Bilbao \\ 062 - Durango \\ 063 - Eibar \\ 064 - San Sebastian \\ 065 - Vera de Bidasoa \\ 082 - Tudanca \\ 083 - Reinosa \\ 084 - Espinosa de los Monteros \\ 085 - Villasana de Mena \\ 086 - Landaco \\ 087 - Elorrio \\ 088 - Vergara \\ 089 -Tolosa \\ 090 - Sumbilla \\ 107 - Barruelo de Santullán \\ 108 - Las Rozas \\ 109 - Villarcayo \\ 110 - Medina de Pomar \\ 111 - Orduña \\ 112 - Vitoria \\ 113 - Salvatierra
}

\author{
114 - Alsasua \\ 115 - Gulina \\ 133 - Prádanos de Ojeda \\ 134 - Polientes \\ 135 - Sedano \\ 136 - Oña \\ 137 - Miranda de Ebro \\ 138 - La Puebla de Arganzón \\ 139 - Eulate \\ 140 - Estella \\ 144 - Ansó \\ 166 - Villadiego \\ 167 - Montorio \\ 169 - Casalarreina \\ 170 - Haro \\ 200 - Burgos \\ 201 - Belorado \\ 202 - Santo Domingo de la Calzada \\ 203 - Nájera \\ 204 - Logroño \\ 213 - Pont de Suert \\ 238 - Villagonzalo-Pedernales \\ 239 - Pradoluengo \\ 241 - Anguiano \\ 242 - Munilla \\ 243 - Calahorra \\ 252 - Tremp \\ 255 - La Pobla de Lillet \\ 258 - Figueres \\ 276 - Lerma \\ 277 - Salas de los Infantes \\ 278 - Canales de la Sierra \\ 279 - Villoslada de Cameros \\ 280 - Enciso \\ 281 - Cervera del Río Alhama \\ 296 - Torroella de Montgri \\ 297 - L'Estartit \\ 314 - Cilleruelo de Abajo \\ 315 - Santo Domingo de Silos \\ 316 - Quintanar de la Sierra \\ 317 - Vinuesa \\ 318 - Almarza \\ 319 - Agreda
}

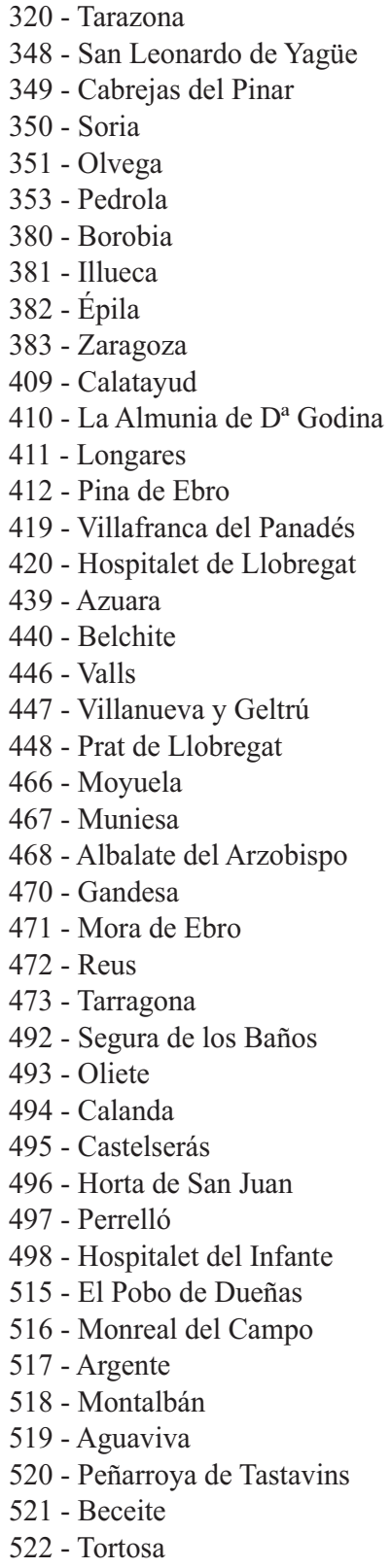


541 - Santa Eulalia

542 - Alfambra

543 - Villarluengo

544 - Forcall

545 - Morella

546 - Ulldecona

547 - Alcanar

564 - Fuertescusa

565 - Tragacete

566 - Cella

567 - Teruel

568 - Alcala de la Selva

569 - Mosqueruela

570 - Albocacer

571 - Vinaroz

587 - Las Majadas

588 - Zafrilla

589 - Terriente

590 - La Puebla de Valverde

591 - Mora de Rubielos

592 - Villahermosa del Río

593 - Cuevas de Vinroma

594 - Alcala de Chivert

610 - Cuenca

611 - Cañete

612 - Ademuz

613 - Camarena de la Sierra

614 - Manzanera
615 - Alcora

616 - Villafames

617 - Faro de Oropesa

634 - San Lorenzo de la Parrilla

635 - Fuentes

636 - Villar del Humo

637 - Landete

638 - Alpuente

640 - Segorbe

641 - Castellón de la Plana

664 - Enguidanos

663 - Valera de Abajo

665 - Mira

666 - Chelva

667 - Villar del Arzobispo

691 - Motilla del Palancar

692 - Campillo Altobuey

693 - Utiel

694 - Chulilla

695 - Liria

719 - Venta del Moro

720 - Requena

721 - Cheste

722 - Valencia

745 - Jalance

746 - Llombay (ojo, repetido)

747 - Sueca

766 - Valdeganga
767 - Carcelén

768 - Ayora

769 - Navarrés

770 - Alcira-Lavisa

791 - Chinchilla de Monte Aragón

792 - Alpera

793 - Almansa

794 - Canals

795 - Játiva

796 - Gandía

817 - Pozo Cañada

818 - Montealegre del Castillo

819 - Caudete

820 - Onteniente

821 - Alcoy

822 - Benissa

823 - Jávea

844 - Ontur

845 - Yecla

846 - Castalla

847 - Villajoyosa

848 - Altea

870 - Pinoso

871 - Elda

872 - Alicante

892 - Fortuna

893 - Elche 